Review

\title{
Antioxidant Activity of Mushroom Extracts/Polysaccharides-Their Antiviral Properties and Plausible AntiCOVID-19 Properties
}

\author{
Sechul Chun (D), Judy Gopal (D) and Manikandan Muthu * \\ Department of Environmental Health Science, Konkuk University, Seoul 143-701, Korea; \\ scchun@konkuk.ac.kr (S.C.); jejudy777@gmail.com (J.G.) \\ * Correspondence: bhagatmani@gmail.com; Tel.: +82-24500574; Fax: +82-24503310
}

\section{check for}

updates

Citation: Chun, S.; Gopal, J.; Muthu, M. Antioxidant Activity of

Mushroom Extracts/

Polysaccharides-Their Antiviral

Properties and Plausible

AntiCOVID-19 Properties.

Antioxidants 2021, 10, 1899. https://

doi.org/10.3390/antiox10121899

Academic Editors: María

Pilar Almajano Pablos and

Stanley Omaye

Received: 24 September 2021

Accepted: 23 November 2021

Published: 26 November 2021

Publisher's Note: MDPI stays neutral with regard to jurisdictional claims in published maps and institutional affiliations.

Copyright: (c) 2021 by the authors. Licensee MDPI, Basel, Switzerland. This article is an open access article distributed under the terms and conditions of the Creative Commons Attribution (CC BY) license (https:// creativecommons.org/licenses/by/ $4.0 /)$.

\begin{abstract}
Mushrooms have been long accomplished for their medicinal properties and bioactivity. The ancients benefitted from it, even before they knew that there was more to mushrooms than just the culinary aspect. This review addresses the benefits of mushrooms and specifically dwells on the positive attributes of mushroom polysaccharides. Compared to mushroom research, mushroom polysaccharide-based reports were observed to be significantly less frequent. This review highlights the antioxidant properties and mechanisms as well as consolidates the various antioxidant applications of mushroom polysaccharides. The biological activities of mushroom polysaccharides are also briefly discussed. The antiviral properties of mushrooms and their polysaccharides have been reviewed and presented. The lacunae in implementation of the antiviral benefits into antiCOVID19 pursuits has been highlighted. The need for expansion and extrapolation of the knowns of mushrooms to extend into the unknown is emphasized.
\end{abstract}

Keywords: mushrooms; polysaccharides; antioxidant; antiviral; antiCOVID-19; bioactivity

\section{Introduction}

Mushrooms belong to the Basidiomycetes group of macrofungi. Mushrooms can grow either above the soil (epigeous), or below the soil (hypogeous). Mushrooms are the choice ingredients of gourmet cuisine globally, encompassing a unique flavor, that works culinary wonders. A total of 2000 species of mushrooms exist, 25 of which are accepted as food and few are commercialized. Mushrooms are also known for their nutritional, organoleptic merits and medicinal properties [1,2]. Their therapeutic qualities, although known much earlier, have recently been acknowledged and valued. The healing properties of mushrooms were known in Chinese traditional medicine even as much as thousands of years before and they are still being used today [3]. Mushrooms abound in essential amino acids, minerals, proteins, and biologically active polysaccharides. They are predominantly consumed in Asian countries, however, in recent years, Pleurotus ostreatus, Boletus edulis, Lentinula edodes (Shiitake), Ganoderma lucidum (Reishi), Trametes versicolor, Grifola fronda (Maitake), Agaricus bisporus and Agaricus subrufescens, have been widely popularized worldwide [4,5].

Mushrooms have the inherent ability to accumulate minerals and vitamins and various other secondary metabolites, such as organic acids, alkaloids, phenols and terpenoids [6]. The production of mushrooms has been continuously on the increase, China being the largest global producer $[1,7,8]$. Wild mushrooms also have their own popularity and nutritional, sensory and pharmacological attributes [2]. Mushrooms are an alternative source of new antimicrobial compounds, terpenes, steroids, anthraquinones, quinolones and benzoic acid derivatives, as well as oxalic acid, peptides, and proteins (primary metabolites. Edible mushrooms possess B1, B2, B12, C, D, and E tannins of nutritional significance $[9,10]$, becoming a rich reservoir of diverse nutraceuticals displaying the synergistic effects of multiple bioactive compounds [11-15]. 
The pharmaceutical potential of mushrooms has in the last few decades escalated, and as of now mushrooms are realized and branded as mini-pharmaceutical factories $[8,16]$. The contents of biologically active substances may vary considerably, affected by variations in strain, substrate, cultivation, developmental stage, age, storage conditions, processing, and cooking practices $[12,13,17]$. However, whatever the case, there is no dearth for bioactive substances in mushrooms. The exhaustive list of acids, terpenoids, sesquiterpenes, polyphenols, lectins, alkaloids, lactones, sterols, metal chelating agents, nucleotide analogs, vitamins, glycoproteins, ergosterols, volatile organic compounds and polysaccharides are there as always.

The current review will focus on the briefly reviewing the biological activity of mushrooms followed by reviewing the antioxidant activity of mushrooms. The antiviral properties of mushrooms, specifically the antiCOVID-19 activity of mushrooms has been elaborately dealt with. The need for improvising the gaps in the proper utilization of this natural resource for positive outcomes has been discussed as a future outlook.

\section{A Snapshot of the Biological Activities of Mushrooms}

Mushrooms are responsible for over a hundred odd medicinal functions. Its key medicinal applications include: antioxidant, anticholesterolemic, anticancer, antidiabetic, antiallergic, immune modulating, cardiovascular protection, antiviral, antibacterial, antiparasitic, anti-inflammatory, antifungal, detox and hepatoprotective effects [18-23]. Various mushroom extracts could mediate decreased activity of inflammatory mediators (nitric oxide (NO), cytokines, and prostaglandins), reducing cell inflammations. Various mushroom extracts have been successfully demonstrated for: immune modulator [24-27], antitumor/anticancer [28-32], antibacterial and antiviral [33-35], antioxidant [36-39], and antihypoglycaemic [40-42] applications and as antiatherosclerotic agents [43]. Shaffique et al. have very recently reviewed the antioxidant attributes of medicinal mushrooms [44]. The efficacy of the bioactive compounds can be largely influenced by the mushroom type, substrate, cultivation conditions and fruiting conditions, stage of development, age, storage conditions and processing and cooking methods [43].

The anticancer milestones of mushrooms have been elaborately reviewed by Ren et al. [45]. We will highlight a few major outlines. Agaricus silvaticus mushrooms, when supplemented in food, reduced glycaemia levels in cancer patients [46] and proved beneficial in patients with colorectal cancer (postsurgery) [43]. A polysaccharide from Grifola frondosa hyped the immune system, when administered orally to breast cancer patients [47]. Japanese researchers confirmed that oral administeration of Lentinula edodes mycelial extracts helped Japanese chemotherapy patients [48-52] and $\beta$-glucan lentinan increased the lifetime of advanced gastric cancer patients [53]. Agaricus silvaticus reduced nausea and abnormal bowel symptoms in those subjected to chemotherapy for breastcancer [54]. A meta-analysis suggested that mushroom intake reduced the incidence of breast cancer [55]. Consumption of mushrooms prevented colitis-associated cancer by reducing cell proliferation and mucosal inflammation [56]. Oral intake of powdered Agaricus bisporus by prostate cancer patients influenced prostate-specific antigens (PSA) and altered the etiology of recurrent prostate cancer through its immuno modulating activity [57-59].

Holmes [60] and Chang et al. [61] confirmed the antiobesity activity of Ganoderma lucidum in mice by altering gut microbiota composition. In a clinical trial in 2009, Johnson et al. [62] confirmed that a daily oral dose of AndoSan (a mushroom extract mixture containing A. blazei mycelium 82\%, Hericium erinaceum 15\%, Grifola frondosa $3 \%$ ) when administered to subjects for 12 days, led to significant in vivo reduction in interleukin-1 (IL-1). The genus Cordyceps includes C. sinensis and C. militaris which are the most valued species in Traditional Chinese Medicine [63]. These have been established for immunological regulation, free radical scavenging, anticancer, antimicrobial, analgesic, antihyperlipidemic, antileukemic and lung improving attributes. The immunomodulatory active substances from mushrooms stimulate immune effector T cells. Cytotoxic dendritic cells (DCs), lymphocytes, T lymphocytes (CTL), macrophages and natural killer (NK) 
cells, resulting in cytokine expression and interleukins (ILs), tumor necrosis factor-alpha (TNF)- $\alpha$, and interferon-gamma (INF) $-\gamma$ are stimulated by bioactive substances from various mushrooms $[64,65]$. Other immunomodulators like lectins, proteins, polysaccharides and terpenoids are also known [66]. Triterpenoids such as lanostane present in wooddecaying mushrooms, Ganoderma sp, exhibiting immunomodulating and anti-infective effects [67-69]. G. lucidum, Grifola frondosa, Flammulina velutipes, Agaricus bisporus, Agaricus blazei, Coprinus cinereus, Cordyceps sinensis, Laetiporus sulphureus, Lentinus tigrinus, Trametes versicolor, Amanita pantherina, Boletus satanas, Ischnoderma resinosum, Lactarius deterrimus and Volvariella volvacea are reputed for their immunomodulatory activities [70-75]. Mushrooms can act as adaptogens and immunostimulators, and their immunostimulatory property is primarily prophylactic and non-invasively prevents infectious diseases and tumor metastases.

The genus Pleurotus has several species that produce mevinolin [76]. Oyster mushroom produced lovastatin; when $5 \%$ of the dried oyster mushroom fruiting bodies was added to a high-cholesterol diet, cholesterol was significantly reduced. Mushrooms are able to redistribute cholesterol in favor of high-density lipids (HDL), reduced production of total cholesterol (TC), very-low-density lipoprotein (VLDL), low-density lipoprotein (LDL), reduced cholesterol absorption and $\beta$-hydroxy $\beta$-methylglutaryl-CoA (HMG-CoA) reductase activity in the liver [77]. Mushrooms are also well known for their antimicrobial activity, $L$ edodes exhibits antimicrobial action against both Gram-positive and Gram-negative bacteria [78] and various other mushroom species have been well established in terms of this attribute.

\section{Antioxidant Activity of Mushrooms}

Researchers have established the fact that the antioxidant activity of mushroom is the genesis of a plethora of bioactivities. Antioxidant compounds have been extracted from fruiting bodies, mycelium and broth of various mushrooms [79]. Mushroom components that are reputed for their strong antioxidant properties include: phenolics, flavonoids, glycosides, polysaccharides, tocopherols, ergothioneine, carotenoids, and ascorbic acid [80-158]. These antioxidant compounds from mushrooms have been identified and quantified using high performance liquid chromatography (HPLC) and gas chromatography (GC), nuclear magnetic resonance (NMR), Fourier transform infrared (FT-IR), UV-VIS spectroscopy and various spectrophotometric assays [12,82-157]. The antioxidant potential of mushrooms is a well-accepted fact. The antioxidant activity of mushroom extracts is measured using methods based on the transfer of electrons and hydrogen atoms, the ability to chelate ferrous $\left(\mathrm{Fe}^{2+}\right)$ and cupric $\left(\mathrm{Cu}^{2+}\right)$ ions, the electron spin resonance (ESR) method, erythrocyte hemolysis, and the monitoring of the activity of superoxide dismutase (SOD), catalase (CAT) and glutathione peroxidases (GPx) [155-157]. Rufoolivacin, rufoolivacin C, rufoolivacin D and leucorufoolivacin have been demonstrated for their ability to scavenge DPPH radicals $[157,158]$. Ramaria flava phenolics aid in scavenging of 2,2-diphenyl-1-picrylhydrazyl (DPPH) and hydroxyl $(\mathrm{OH})$ radicals $[159,160]$. Ferreira et al. have published an excellent review on the antioxidants in wild mushrooms [13]. This review chooses to highlight the biological impacts of mushroom polysaccharides and their antioxidant activity.

\subsection{Bioactivity of Mushroom Extracts and Their Polysaccharides}

Pleurotus spp. have a vast diversity of polysaccharides, particularly heteropolysaccharides and glucans [161]. These polysaccharides from the genus Pleurotus spp. are known to carry special biological activities. Ruthes et al. (2016), in their review article, have reported that mushrooms are abundant in heteropolysaccharides [4]. Heteropolysaccharides possess anti-tumor, antioxidant, anti-inflammatory, and immunomodulatory activity. Barbosa et al. (2020b) employed a special supercritical binary hot water and $\mathrm{CO}_{2}$ system to extract polysaccharide-rich fractions from Pleurotus ostreatus [162] and their antioxidant potential has been demonstrated in cell models. Phallus atrovovatus is known to possess abundant polysaccharides, predominantly fractions of $\beta$-glucan and $\alpha$-glucan. These polysaccharides exhibited immune system modulating activity and high anti-inflammatory activity [163]. 
Mingyi et al. (2019) showed that mushroom polysaccharides are high functionality biomolecules [164]. The review consolidates the use of polysaccharides in foods, as medicines and in cosmetics and its future as a functional food. Polysaccharides have now fully recognized as the major bioactive components of mushrooms $[165,166]$, which are bound to the mushroom cell wall by covalent (ester) linkages [84]. As already specified, the most widely reported activity of mushroom polysaccharides is antioxidative [82,83,85,87-113]. Briefly, we now review and present a consolidated account of the various reports on the antioxidant activity of mushroom polysaccharides published thus far. It is believed that purified mushroom polysaccharides exhibit lower antioxidant activities than their original crude extracts [95], while others reported high antioxidant activity in pure polysaccharide fractions. A. brasiliensis polysaccharides (consisting mainly of $(1 \rightarrow 6)-\beta$-D-glucans) obtained by pronase deproteinization exhibited high antioxidative activity against ${ }^{\bullet} \mathrm{OH}$ and $\mathrm{O}_{2}{ }^{\bullet-}$ radicals [109]. $\beta$-glycans are the predominant antioxidative components in mushrooms and are responsible for activating systemic responses $[167,168]$. Thus, they are the jackpots of mushroom polysacchrides in terms of their bioactive potential. Mushroom polysaccharides and glycoconjugates are now becoming ideal candidates for creating new nature-based medications, for dietary supplements and for treatment of oxidative stress-mediated disorders. Polysaccharides also help prevent lipid peroxidation and the pathogenesis of various gastro intestinal (GI) diseases, such as peptic ulcers, GI cancers and inflammatory bowel disease which stem from oxidative stress $[169,170]$.

Mushroom polysaccharides also display antimicrobial properties against pathogenic bacteria and viruses. Data on mushroom polysaccharides for different basidiomycetes indicated the presence of rhamnose, xylose, fucose, arabinose, fructose, glucose, mannose, mannitol, sucrose, maltose and trehalose as the predominant mushroom-based polysaccharide fractions [171]. Klaus et al. [86] encapsulated polysaccharide extracts from G. frondosa in alginate gel beads to protect them from external influences and extend their applications. Mushroom polysaccharides have been extracted from: A. blazei [172], A. brasiliensis [173], A. ponderosa [174], oyster mushroom [175], A. polytricha [176], B. edulis [177], C. tricholoma [178], C. militaris [179], Entolomalivido album [180], Gleoestereum incarnatum [181], G. lucidum [182], Grifola frondosa [183,184], Hohenbuehelia serotina [185], Hypsizygus marmoreus [186], Iliodiction cibarium [41,45], Lactarius deliciosus [187], L. edodes [188], Macrolepiota dolichaula [189], Phellinus igniarius [190], Phellinus linteus [191], Phellinu spini [192], Pholiota adiposa [193], Pholiota nameko [194], Pleurotus eryngii [195], P. ostreatus [196], Termitomyces heimii [197], Tricholoma matsutake [198-201], Tricholoma mongolicum [202].

Likewise, mushroom polysaccharides are becoming increasingly well suited against obesity. Combination cancer therapy using a Grifola frondosa $\beta$-glucan fraction and an oligodeoxynucleotide is reported [203]. Pan et al. [204] showed that Amauroderma rude polysacchrides inhibit tumor in mice. Encapsulation of Antrodia camphorata polysaccharides in chitosan-silica/silica nanoparticles increased the anti-tumor activity of HepG2 liver cancer cells [205]. Polysaccharide-contents of Hericium erinaceus extracts inhibited migration of cancer from colon tumors to lungs in murine models [206]. Lentinula edodes enhanced immunity in healthy young people and oral intake of soluble $\beta$-glucans in elderly healthy adults increases the number of circulating $\beta$-cells [207]. Meng et al. [208] and Yan et al. [209] have elaborately discussed the link between structural characteristics of mushroom polysaccharides and their other relational antitumor aspects. Schwartz and Hadar [56] have reviewed the possible mode of action of mushroom $\beta$-glucans against cancer associated with inflammatory bowel disease in humans. Mushroom polysaccharides seem to orchestrate antitumor properties via activation of the host immune response. Thus, it is inferred that mushroom polysaccharides do not directly destroy tumor cells; instead, they indirectly make an impact by preventing stress on the body, leading to a $50 \%$ reduction in the size of the tumor, thereby prolonging the survival time of the tumor-bearing mice [51,177].

Supplementation with $\beta$-glucan from Pleurotus ostreatus is reported to protect athletes from respiratory tract infections [210]. Silver nanoparticles were synthesized using glucan 
from Pleurotus florida. This could inhibit Klebsiella pneumoniae synergistically (along with four medicinal antibiotics) [211]. Pleurotus nebrodensis polysaccharide enhanced immunity and inflammatory responses by activating macrophages [37]. An exopolysaccharide from Clitocybe maxima increased the immunological response and inhibited tumor cells in mice [64,212]. Manna et al. [198] synthesized nanoparticles using a Lentinus squarrosulus hetero polysaccharide and successfully demonstrated it against $E$. coli and other bacteria. The nanoparticles were better than normal particles in inhibiting bacteria and viruses. Mushroom polysaccharides shielded mice against Salmonella lipopolysaccharide-induced septic shock [213]. The same polysaccharide combined with Hericium erinaceus extracts protected mice against Salmonella typhimurium by stimulating the immune system [214]. Lentinus edodes extracts were demonstrated against oral pathogens [215], while Auricularia auricula-judae crude polysaccharides were active against Escherichia coli and Staphylococcus aureus [216]. A sulphated polysaccharide from oyster mushrooms showed antibacterial activity against foodborne E. coli and Staphylococcus aureus [217]. Polysaccharides from Hericium erinaceus have been of considerable interest due to their antioxidant activities [218]. Polysaccharides from eight Hericium species exhibited significantly high antioxidant activity and inhibited proliferation of tumor cells [219]. In another report, bismuth-polysaccharide complexes could inhibit Helicobcter pylori, which cause human ulcers and eventual cancers [220].

Huang et al. [221,222] showed that Pleurotus tuber-regium polysaccharides exhibited antihyperglycemic properties and lowered oxidative stress in diabetic rats. Agaricus blazei polysaccharide extracts impacted proinflammatory cytokine production in human monocytes and endothelial cells [223] and other bioactive fractions as well (IL-6, prostaglandin $\mathrm{D}(2)$, leukotriene $\mathrm{C}(4))$. L. edodes active fucomannogalactan fractions of $(1 \rightarrow 6)$-linked main chains have shown anti-inflammatory activities in male Swiss mice [202]. The polar fraction the $\beta$-glucan-rich mushroom preparation AndoSan ${ }^{\mathrm{TM}}$ showed antitumor activity in RAW 264.7 macrophage cells. $\beta$-glucans show anti-asthma and antitumor properties, as well as anti-inflammatory effects in inflammatory bowel disease [224]. With all these added assets, nevertheless a study where AndoSan ${ }^{\mathrm{TM}}$ was administered to 40 patients with multiple myeloma due for chemotherapy, no significant responses were observed [225]. This indicates that there is a long way to go for all these to be worked out in order to practically demonstrate statistically significant responses in real time.

Agaricus blazei extract increased immune response against foot-and-mouth disease [226] and H. erinaceus extracts shielded the mice against Salmonella typhimurium [227] and L. edodes mycelial polysaccharids defended mice against Salmonella-induced endotoxemia and salmonellosis [216]. Another study by Kim et al. confirmed the protective effect of $C$. sinensis extracts on the lipopolysaccharide induced lung injury in mice. The extracts reduced TNF- $\alpha$, IL-6, IL-1 $\beta$ expression, as well as the binding ability of NF- $\mathrm{kB}$ p65 DNA and inhibitied the mRNA expression of cyclooxygenase (COX)-2 and inducible nitric oxide synthase (iNOS) in lung tissue [228]. C. sinensis, was proposed by the same authors as for treatment of acute lung injury. Yang et al. [229] reported the use of $C$. sinensis towards the inhibition of bleomycin-induced fibrosis in mice, to prevent and treat lung fibrosis. Mueller et al. [230] and Jiang et al. [231] have confirmed that $C$. sinensis inhibits lung fibrosis. These results are supported by Lee et al. [232], who showed that cordycepin from $C$. militaris downregulates iNOS, COX-2 expression and TNF- $\alpha$ gene expression. Additionally, Ohta et al. [233] showed that cordycepin reduced Th2 associated cytokines, including IL-4, IL-5 and IL-13, in Ova-induced asthma mice.

A total of 14 species of Basidiomycetes mushroom cultures were studied. All these species showed $20 \%$ more antioxidant potential. [234]. Other authors quantified the antioxidant potential of Ganoderma lucidum, Ganoderma tsugae, Coriolus versicolor, G. tsugae and G. lucidum methanolic extracts. Their antioxidant activity is driven by their phenolic contents. [235]. In 2008, Kim et al. investigated the antioxidant potential of edible medicinal mushrooms, Agaricus bisporus showed the highest activity. They reported a 78\% positive correlation between phenolics and antioxidant potentials [236]. The antioxidant potentials of methanolic extracts of shiitake and oyster mushrooms using the 1,3-diethyl-2- 
thiobarbituric acid method were reported to be due to their phenolic contents [237]. The antioxidant potentials of five methanolic extracts of ear mushrooms, including red, black, jin, snow, and silver ear mushrooms were determined. The methanolic extracts contained bioactive tocopherol, polyphenols and ascorbic acid and the snow ear variety possessed maximum antioxidant potential [105].

The antioxidant potential of ethanolic extracts of Laetiporus sulphureus was studied. A positive correlation between polyphenol contents and antioxidant potential was observed. The antioxidant potential of various Morchella sps and Meripilus giganteus, Armillaria mellea, Paxillus involutus, Pleurotus eryngii, and Pleurotus ostreatus, via the DPPH method was measured. Among these, M. elata possessed the maximum antioxidant potential toward free radicals [238]. Methanolic extracts of Inonotus obliquus also possessed strong antioxidant potentials owing to their polyphenols, such as inonoblins A-C and phelligridins D, E, and G. [239]. The antioxidant and hepatoprotective pattern of Lentinus edodes was validated in an independent study, using mice models [240].

An in vitro study conducted in Iran confirmed the antioxidant potential of Cantharellus cibarius and Pleurotus porrigens methanolic and ethyl acetate extracts, via the DPPH method [241]. Hot water extracts of Agaricus, Antrodia, Auricularia, Coprinus, Cordyceps, Hericium, Grifola, Ganoderma, Lentinus, Phellinus, and Trametes were tested for their antioxidant potential. Polyphenolic compounds and polysaccharides were responsible for the high antioxidant potential of all these studied mushrooms. Among all, Ganoderma was the most antioxidant mushroom [103]. The antioxidant activities of two cultivated mushrooms- $P$. ostreatus and L. edodes-and five other wild mushrooms from Ethiopia were compared. Results indicated that $A$. campestris exhibited significant antioxidant potential due to its phenolic compounds [103]. The Polyporoid species of medicinal mushrooms native to Poland were studied. The results showed that it contains protocatechuic, vanillic, and hydroxybenzoic acids and that phenolic compounds were behind their antioxidant potentials.

The antioxidant potential of Pleurotus eryngii, due to its phenolic contents, revealed that it has excellent antioxidant activity and was able to scavenge free radicals and possessed reducing power. It also contained ergothioneine, making it a successful functional food [242]. G. lucidum was observed to possess high phenolic contents and significant antioxidant activity and potential as a good functional food [243]. Ganoderma tsugae showed high antioxidant levels owing to its phenols [244]. For the Leucopaxillus species, negative linear regressions were seen between flavonoids, which increased with the antioxidant activity [245]. Pleurotus ferulae, Clitocybe maxima, and Pleurotus ostreatus were selected for antioxidant study and their antioxidant potentials measured. The results showed that they contained phenolic compounds that helped them fight the oxidative stress system [246]. Methanolic extracts of Pleurotus porrigens and Hygrocybe conica indicated that Hygrocybe conica possessed higher chelating and antioxidant properties due to their total phenolic components [247]. Other authors have reported the antioxidant and the anti-inflammatory effects of Malaysian G. lucidum aqueous extracts; their study proved that these extracts exhibited higher antioxidant and anti-radical effects [248,249]. We will now elaborate on the reports on how mushroom polysacchrides antioxidants have been used in various applications.

\subsubsection{Antioxidant Mushroom Extracts and Polysaccharide Applications}

Most mushrooms contain polysaccharides that include chitin, glucans and heteroglycans. These polysaccharides are instrumental in coordinating the growth and developmental processes of the mushroom's fructiferous body. Polysaccharides play an important role in modulating the immunity of human cells [250]. Immunomodulating polysaccharides such as $\beta$-glucans are non toxic and have no secondary effects while being used against bacteria and viruses [45]. They also display antitumor and immunostimulating properties [251]. The antioxidative and immunostimulating properties of Cordiceps militaris polysaccharides were able to suppress the in vivo growth of melanoma in mouse 
models [252]. Antioxidative properties of a crude polysaccharide from Inonotus oblique (folk medicine in Russia)include rich medicinal and nutritional properties [253]. A polysaccharide from Hericium erinaceus exhibited strong in vitro antioxidant activity and liver damage protection [254]. Macrolepiota dolichaula fucogalactan [193] and $\beta$-glucan from Russula albonigra [255] showed excellent antioxidant activity. H. erinaceus polysaccharide exhibited antioxidant and neuroprotective effects [256]. A polysaccharide from Agaricus brasiliensis induced immunostimulation and cell proliferation in vitro in mice $[257,258]$. Polysaccharides extracted from Tricholoma mongolicum displayed in vitro antioxidant activity [201]. Ultrasonically extracted Ganoderma $\beta$-D-glucans were reported to possess better in vitro antioxidant activity than conventionally extracted ones [191,259], owing to the fact that the ultrasonic extraction preserved their molecular weights and degree of branching. A water-soluble $\beta$-glucan, isolated from the fruit bodies of Entoloma lividoalbum, stimulated the production of macrophages, splenocytes and thymocytes and exhibited hydroxyl and superoxide radical scavenging activities and reducing properties [260]. A fucogalactomannan from Tylopilus ballouii mushroom inhibited superoxide and hydroxyl radicals and reduced edema [261].

In another study, polysaccharides from eight Chinese mushrooms were evaluated for their total carbohydrate, polyphenolic and protein contents, and antioxidant and antiproliferation activities. The results suggested that all the polysaccharides had significant antioxidant capacities. The acid extracts of Russula vinosa had the highest $\mathrm{ABTS}^{+}$scavenging activity, and Dictyophora indusiata and Hohenbuehelia serotina possessed the highest ${ }^{\bullet} \mathrm{OH}$ scavenging capacity and ability to inhibit lipid peroxidation [262].

M. Kozarski compared polysaccharides of A. bisporus, A. brasiliensis, Phellinus linteus, and G. lucidum and their other bioactive components. A positive correlation between glucan level and antioxidant activity was reported in case of G. lucidum. [84]. A study conducted by The University of Calcutta revealed that Pleorotus squarrosulus, Fistulina hepatica, Austreus hygrometricus, Polyporus grammocephalus, Phellinus linteus and Macrocybe gigantea, have high antioxidant activity [263]. Methanolic extracts of the wild Ganoderma lucidum, native to the Himalayas, showed significant antioxidant potential [264]. The antioxidant potentials of Volvariella volvacea [265], Ganoderma tsugae, Morchella conica, [266], Ganoderma lucidum, Hypsizygus marmoreus, P. ostreatus, P. nebrodensis, Lentinus edodes, Pleurotus eryngii, Flammulina velutipes, and Hericium erinaceus are clearly documented [249,267]. Further study was also conducted to assess the effectiveness of medicinal mushrooms on MCF-7 breast cancer cell lines. The results showed that G. lucidum polysaccharides wroked well against MCF-7 cell lines [221]. The antioxidant potential of Taiwanese Cordyceps taii is also reported [268].

\subsubsection{Mechanism of Antioxidant Mushroom Polysaccharides}

The antioxidant properties of mushrooms are related to the bioactive compounds in mushrooms. Mushrooms are the primary source of ergothioneine, which protects the mitochondrial components from oxidative damage. This is orchestrated by generation of $\mathrm{O}_{2}{ }^{\bullet-}$ through the escape of electrons from the mitochondrial electron transport system (ETS) [269]. The antioxidative activity of mushroom polysaccharides is attributed to their RS scavenging ability, reduction property and ability to chelate $\mathrm{Fe}^{2+}$, inhibit lipid peroxidation, erythrocyte hemolysis and the increase in enzyme activities in eukaryotic and prokaryotic cells and their roles in ongoing SOD, CAT and GPx antioxidative processes [270].

The potency of mushroom polysacchrides to scavenge free radicals is owing to the presence of hydrogen in certain monosaccharide units and their binding in side branches of the main chain $[94,121]$. The enhanced antioxidant activity is owing to the abstraction of the anomeric hydrogen from one of the internal monosaccharide units rather than from the reducing end [271]. Recently, Kishk and Al-Sayed [272] reported that the ${ }^{\bullet} \mathrm{OH}$ scavenging mechanism of polysaccharides is same as that of phenol compounds. The mechanism is dictated by hydrogen atom transfer (HAT) reactions. These reactions mostly occur in neutral polysaccharides, while the electron transfer (ET) mechanism usually occurs in acidic polysaccharides. Mushroom antioxidants act in varying stages and via 
different mechanisms $[13,273]$. There are two main types of mushroom antioxidants, namely, primary (chain breaking, free radical scavengers) and secondary or preventive [84, $97,103,125,136,152-154]$ antioxidants. Secondary antioxidants manifest from deactivation of metals, inhibition or breakdown of lipid hydroperoxides, regeneration of primary antioxidants, or singlet oxygen $\left(1 \mathrm{O}_{2}\right)$ quenching processes [80]. In certain other cases, mushroom ROS scavengers act in oxidation-reduction reactions that are reversible, and as antioxidants and pro-oxidants. The optimization of antioxidant dietary supplements from mushrooms is far from accomplished $[17,42,185]$. Table 1 summarizes the list of mushroom polysaccharides and their antioxidant activity.

Table 1. Bioactivity of Mushroom Polysaccharides.

\begin{tabular}{|c|c|c|c|}
\hline Source Mushroom & Bioactive Component & Antioxidant Activity & References \\
\hline Agaricus brasiliensis & Crude Se polysaccharide & Scavenging of DPPH and hydroxyl radicals & [272] \\
\hline Phellinus xiaobaumii & $\begin{array}{l}\text { Homogenous water } \\
\text { soluble polysaccharide }\end{array}$ & $\begin{array}{l}\text { Hydroxyl, superoxide and DPPH radical } \\
\text { scavenging }\end{array}$ & [274] \\
\hline Pleurotus abalonus & $\begin{array}{l}\text { Polysaccharide-peptide } \\
\text { complex LB-1b }\end{array}$ & $\begin{array}{l}\text { Antioxidant activity in erythrocyte } \\
\text { haemolysis }\end{array}$ & [275] \\
\hline Cordyceps taii & Polysaccharides & $\begin{array}{l}\mathrm{DPPH}, \text { hydroxyl, and superoxide anion } \\
\text { radical scavenging }\end{array}$ & [268] \\
\hline Agaricus bisporus & Polysaccharides & $\begin{array}{l}\text { Free radical scavangers enhancement of } \\
\text { antioxidant enzymes in sera, liver, and heart } \\
\text { of mice }\end{array}$ & [276] \\
\hline Ganoderma lucidum & $\begin{array}{l}\text { Heteroglycan, } \\
\text { mannoglucan, } \\
\text { glycopeptide }\end{array}$ & Antioxidant & {$[34]$} \\
\hline Pleurotus ostreatus & Glycoprotein & Antitumor, hyperglycemia, antioxidant & [34] \\
\hline Cordiceps militaris & Polysaccharides & $\begin{array}{l}\text { Antioxidant activity suppression of in vivo } \\
\text { growth of melanoma in mouse models }\end{array}$ & {$[251,252]$} \\
\hline Inonotus oblique & Crude polysaccharide & $\begin{array}{l}\text { Used as an antioxidant in Russian folk } \\
\text { medicine }\end{array}$ & [253] \\
\hline Hericium erinaceus & $\begin{array}{l}\text { Unique polysaccharide } \\
\text { EP-1 }\end{array}$ & Strong in vitro antioxidant activity in mice & [254] \\
\hline Macrolepiota dolichaula & Fucogalactan & $\begin{array}{l}\text { Antioxidant and immunostimulating } \\
\text { properties in vitro }\end{array}$ & [189] \\
\hline Russula albonigra & $\beta$-glucan & $\begin{array}{l}\text { Antioxidant and immunostimulating } \\
\text { properties in vitro }\end{array}$ & [255] \\
\hline Tricholoma mongolicum & Folysaccharides & In vitro antioxidant activities & [202] \\
\hline Ganoderma & $\beta$-D-glucans & In vitro antioxidant activity & [259] \\
\hline Entoloma lividoalbum & Water soluble $\beta$-glucan & High antioxidant activity & [260] \\
\hline Tylopilus ballouii & Fucogalactomannan & Inhibiting superoxide and hydroxyl radicals & [261] \\
\hline Ganoderma lucidum & $\alpha$-and $\beta$-glucans & High antioxidant activity & [262] \\
\hline $\begin{array}{l}\text { Fistulina hepatica, Pleorotus squarrosulus, } \\
\text { Polyporus grammocephalus, Phellinus } \\
\text { linteus, Austreus hygrometricus, and } \\
\text { Macrocybe gigantea }\end{array}$ & Polysaccharides & Significant antioxidant potential & [263] \\
\hline Ganoderma tsugae & Polysaccharides & Best scavenging activity & [268] \\
\hline $\begin{array}{l}\text { Ganoderma lucidum, Hypsizygus } \\
\text { marmoreus, Pleurotus ostreatus, Pleurotus } \\
\text { nebrodensis, Lentinus edodes, Pleurotus } \\
\text { eryngii, Flammulina velutipes, and } \\
\text { Hericium erinaceus }\end{array}$ & $\begin{array}{l}\text { Polysaccharide activity } \\
\text { compared }\end{array}$ & Significant antioxidant potential & [249] \\
\hline
\end{tabular}


Figure 1 enlists the known mechanisms of antioxidant activity of mushroom polysaccharides elucidated to date.

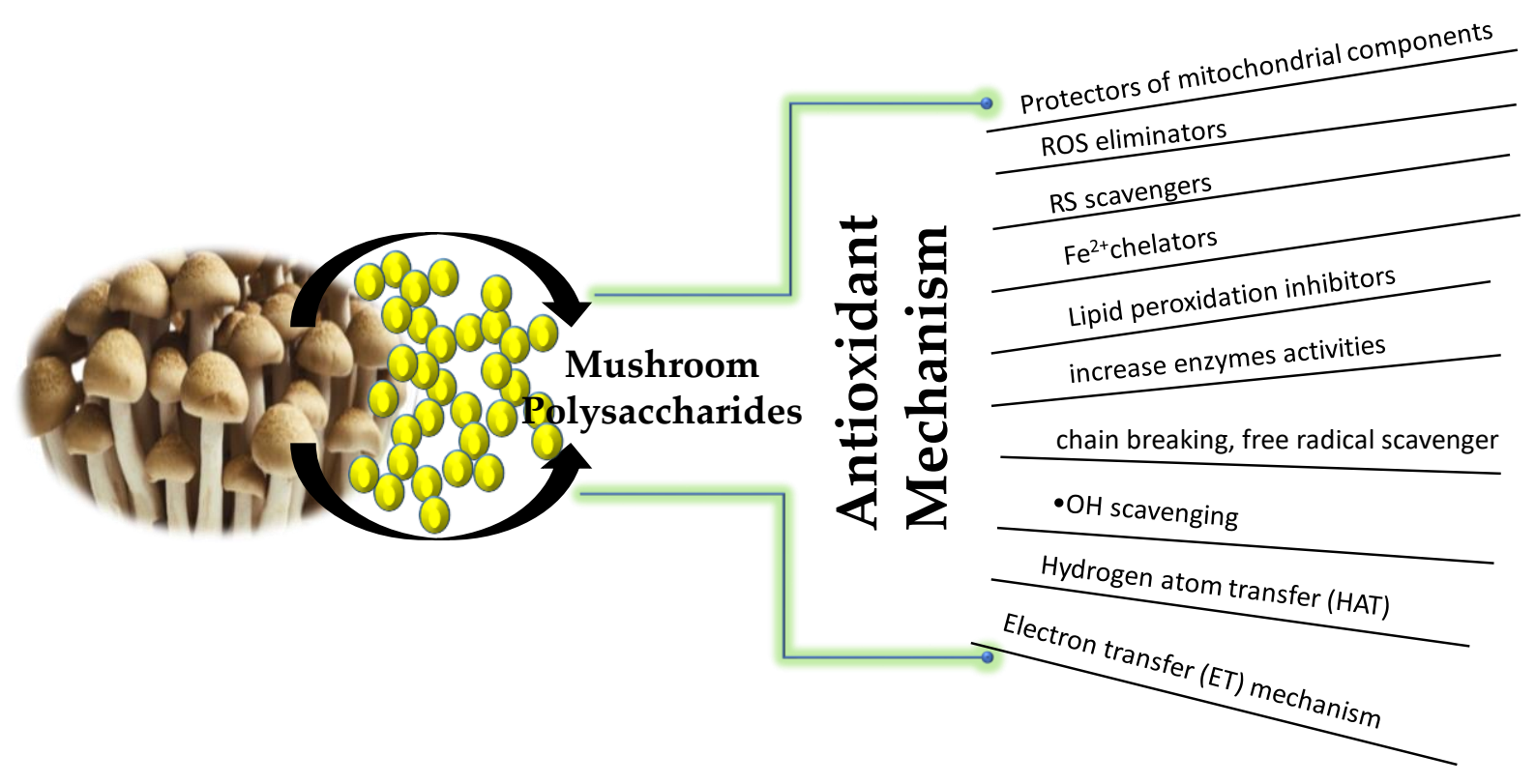

Figure 1. Antioxidant mode of action of mushroom polysaccharides.

\section{Antiviral Activity of Mushrooms/Mushroom Polysaccharides}

The antiviral activity of mushrooms is another add-on to the exhaustive bioactivities of mushrooms. Wild mushrooms from Russia, such as Daedaleopsis confragosa, Datronia mollis, Ganoderma valesiacum, Irpex lacteus, Ischnoderma benzoinum, Laricifomes officinalis, Lenzites betulina, Phellinus conchatus, Piptoporus betulinus, Trametes gibbosa, and Trametes versicolor have been shown to have antiviral activity on A/chicken/kurgan/05/2005 (H5N1) bird virus and the A/Aichi/2/68 (H3N2) human virus. The report confirmed that these mushrooms produced antiviral substances that block the synthesis of viral enzymes and boost human immunity [277]. Another study in Russia in 2020, by Ilyicheva et al., assessed the antiviral effect of ethanol and water extracts of Pleurotus pulmonarius fructiferous body against the A/California/07/09(H1N1pdm) virus, the results showing that the ethanol extracts had a more powerful antiviral effect than the water extracts. This mushroom's fructiferous body is an important source of polysaccharides, which are responsible for the inhibitory activity against infections caused by this flu virus [278]. The water extract of Pleurotus tuber-regium, containing $\beta$-glucans, was demonstrated against herpes simplex virus type 1 (HSV-1), herpes simplex virus type 2 (HSV-2), respiratory syncytial virus (RSV) and influenza A virus (Flu A), which was tested by Zhang et al. in 2004 [279]. The tests confirmed powerful antiviral effect against HSV1 and HSV-2. Water and methanolic extracts of Boletus edulis, Lentinus edodes and Pleurotus ostreatus were tested against the herpes simplex type 1 (HSV-1) viruses and water extracts were observed to show high antiviral activity. The highest antiviral effect was found in Lentinus edodes extracts, followed by Boletus edulis and finally by Pleurotus ostreatus [280].

Agaricus brasiliensis' antiviral activity was proven by Faccin et al., where polysaccharides from water and ethanol extracts were successfully demonstrated against type 1 poliovirus, which is one of the mushroom species that grows on tree stumps, having been domesticated in order to be cultivated [281]. In 2007, Gu et al. [282] and in 2016 Zhao et al. [283] evaluated the antiviral activity of Grifola frondosa against enterovirus 71 and HSV-1. These reports confirmed the antiviral effects of polysaccharides and their potent use as therapeutic antiviral agents. Inonotus obliquus is a parasite mushroom that lives up to 20 years; in 2011, Shibnev et al. used water extracts of this mushroom against hepatitis C virus [284]. The extracts inhibited the infectious viruses in the kidney cells of 
a pig embryo. Methanolic extracts from Pleurotus $s p$. and Lentinus $s p$. were used against cytomegalovirus (HCMV) [285]. In another study, $\beta$-glucans of Pleurotus ostreatus were used to control influenza viral infection of the respiratory tract in children [286].

Some HIV-1 protease inhibitors have been isolated from medicinal mushrooms. Various components that possess anti HIV-1 protease activity have been isolated from Ganoderma lucidum (ganolucidic acid A, $3 \beta$-5 5 -dihydroxy- $6 \beta$-methoxyergosta-7,22-diene, ganoderic acid $\mathrm{A}-\mathrm{C}$, ganoderic acid $\beta$, ganodermanondiol, ganodermanontriol and lucidumol B) [287-289]. Six colossolactones, ganomycin I, and ganomycin B, isolated from G. colosum, with anti-HIV-1 protease activity have been reported, as also in G. sinnesse [290,291]. Tiger milk mushroom (Lignosus rhinocerus) and Auricularia polytricha also exhibited HIV-1 protease activity [292].

Adenosine and iso-sinensetin isolated from Cordycep militaris and $4.5 \mathrm{kDa}$ protein isolated from Russula paludosa have been demonstrated to have anti-HIV-1 protease activity [293]. C. sinensis and C.militaris are known to exhibit antiviral effect on several viruses. In 1991, Mueller et al. [230] reported the in vitro antiviral effect of cordycepin on HIV-1. Therefore, Jiang et al. [231] reported the HIV-1 protease inhibitory on adenosine from C. militaris. Lee et al. [232] recorded the antiviral effect of C. militaris on DBA/2 mice infected with H1N1; the mice showed significant survival improvement following C. militaris treatment and marked decrease in TNF- $\alpha$ Kaymakci and Güler. C. militaris' anti-influenza effect was confirmed by Ohta et al. [233]; they reported significant decrease in virus titers in both lung tissue and the bronchoalveolar fluid of mice, when treated with an acidic polysaccharide (APS) isolated from C. militaris intranasally. The anti-influenza effect of the APS is probably due to its immunomodulatory effects [232]. In addition to anti-HIV and anti-influenza activities, C. militaris also exhibits an anti-HCV effect [294]. They also reported that cordycepin was probably instrumental in pulling through this activity by inhibiting RNA-dependent RNA-polymerase (NS5B) in HCV [295]. C. sinensis and $C$. militaris can modulate immune responses as well as anti-inflammatory, antiviral, antioxidant, and antifibrotic properties. It may be suitable for the pathologies that occur in COVID-19 [296-298].

Another species of mushroom that has shown promising antiviral effects is Grifola frondosa, which has been used in herbal medicine. The major biologically active component here is $\beta$-glucan. Grifola $\beta$-glucan has shown great anticancer potential and has been approved as a therapeutic drug for cancer in China [299] and in vitro replication of HSV type 1 (HSV-1) [300]. Gu et al. (2007) confirmed that topical administration of the protein extract to the cornea of mice caused a significant decrease in virus [282]. Additionally, D-fraction from Grifola frondosa (GF-D), together with human IFN $\alpha-2 b$ (IFN), was used against hepatitis $b$ virus (HBV). Following analysis of HBV DNA and viral antigens, the results obtained showed that GF-D or IFN could control the HBV DNA in cells. Combined use of GFD and IFN synergistically inhibited HBV replication [301].

Significant increase in pro-inflammatory mediators, COX-2, pro-inflammatory cytokines TNF- $\alpha$, IL-1 $\beta$ and IL-6 in LPS-stimulated human U937 macrophage cells is reported. The hot water extracts of P. A+ strain mushroom significantly inhibited the LPS-induced COX-2 while the other extracts lowered the levels non-significantly [302]. The study also revealed that the four hot water mushroom extracts of Pan cyanescens, $P$. natalensis, $P$. cubensis and P. A+ strain significantly the two key pro-inflammatory cytokines TNF- $\alpha$, IL-1 $\beta$ inhibited in a dose-dependent manner. Suppression of the induced IL-1 $\beta$ and the lowering of COX-2 following exposure to mushroom extracts indicated their potential in inflammation-related diseases. P. natalensis and P. cubensis inhibited LPS-induced IL-6 in human U937 macrophage cells. The extracts also marginally increased the concentrations of the anti-inflammatory cytokine IL-10 in the treated human macrophage cells [303-305]. Well-known anti-inflammatory and antioxidant compounds have been identified in $P$. natalensis [306]; other studies confirmed significant inhibition of ROS displayed by Pan cyanescens and P. cubensis in a pathological hypertrophy condition [307]. Excessive amounts 
of ROS stimulate the release of cytokines and subsequent activation of COX and LOXs signaling, playing a role in inflammatory reactions.

The three mushrooms Pleurotus columbinus, Pleurotus sajor-caju, and Agaricus bisporus contain a myriad of bioactive compounds. Aqueous extracts of these mushrooms were tested against Ad7 and HSV2 viruses. The extracts show potent antioxidant effects. Pleurotus columbinus, Pleurotus sajor-caju and Agaricus bisporus mushrooms offer significant medicinal potential for the prohibition and treatment of a variety of ailments [308]. Figure 2 gives an overview of the comprehensive list of viruses and the mushroom polysaccharides that have been reported to engage in antiviral activity.

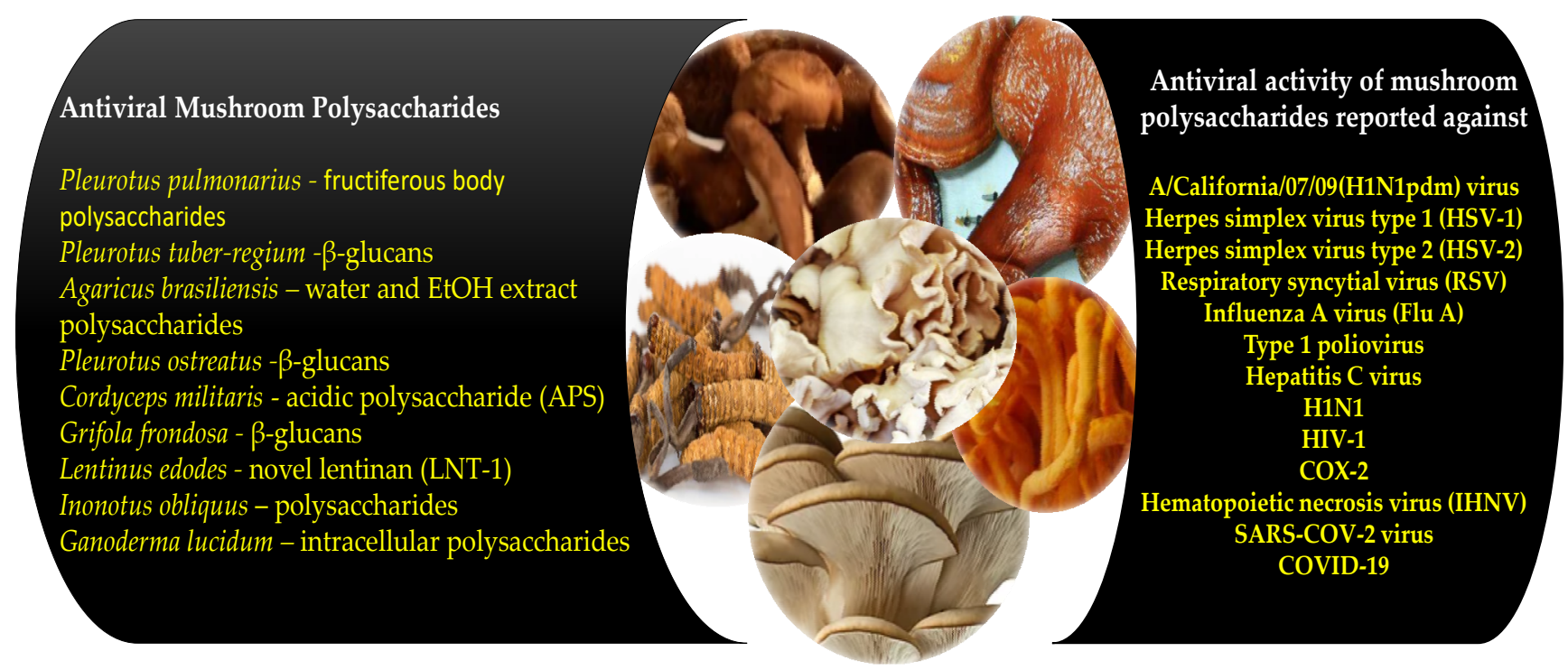

Figure 2. Overview of antiviral mushroom polysaccharides and impacted viruses.

\section{AntiCOVID-19 Activity of Mushroom Polysaccharides}

The world has been suffering from the effects of the 2019 COVID-19 pandemic. As of now, limited provisions are available with respect to control, treatment and spread of COVID-19 [309-311]. As of now, there are few treatments available for COVID-19. The U.S. Food and Drug Administration (FDA) has approved remdesivir (Veklury) for the treatment of COVID-19. Monoclonal antibodies are laboratory-made molecules that act as substitute antibodies, by equipping the immune system to recognize and respond effectively to the virus, slowing down viral reproduction and virulence. The FDA has issued EUAs for several monoclonal antibody treatments for COVID-19 for the treatment of mild or moderate COVID-19 in adults and pediatric patients. Approved therapies using small molecules and monoclonal antibodies that have been demonstrated to be effective against COVID-19 and the proven efficacy of vaccination are also affirmed. The first pill designed to treat symptomatic COVID-19 has been approved by the UK medicines regulator as of November 2021. Molnupiravir, developed by the US drug companies Merck, Sharp and Dohme (MSD) and Ridgeback Biotherapeutics, is the first antiviral medication for COVID-19 which can be taken as a pill. Although to date there are some options, there still exists a pressing urgent need to discover novel natural antivirals that are cost-effective and exhibit enhanced anti-COVID-19 efficacy. Using an artificial intelligence (AI) programme, researchers identified components that can interfere with clathrin-mediated endocytosis and thus inhibit viral infection. These can be deployed as potential therapeutics against COVID-19 [312]. However, the problem with commercial medications is the increased risk of drug resistance development. Natural substances, such as mushrooms that have been previously discussed in the above section, clearly displayed antiviral and anti-inflammatory activity. With this as the launching pad, there is definitely scope to believe that mushrooms 
may hold natural remedies against COVID-19 [313]. We present the available reports in this direction.

Vilcek and Lee, in 2018 [314], elucidated the structural characterization of lentinan from Lentinus edodes mycelia (shiitake) and their associated anti hematopoietic necrosis virus (IHNV) potential. The novel lentinan (LNT-1) confirmed prominent antiviral activity against INHV. The antiviral mechanisms of LNT-1 were reported to be due to direct inactivation as well as inhibition of viral replication and downregulation of pro-inflammatory cytokines that are known to induce antiviral, anti-proliferative and immunomodulatory effects [315]. In case of COVID-19, the innate immune response is a critical factor for disease severity and disease outcome. COVID-19 patients exhibit high titers of inflammatory cytokines and so the effects of LNT-1 could clearly impact and lead to anti-COVID-19 acitivity [316]. Moreover, oxidative stress and inflammation are two factors that are consistently linked to the pathogenesis of COVID-19; both these factors are well within the bioactivity of mushroom based components [317].

Inonotus obliquus (IO) is expected to be a valuable asset against SARS-CoV-2 virus [318]. IO is well accomplished in traditional medicine, for facilitating breathing, because this mushroom has been known reduce nasopharyngeal inflammation $[88,284,319]$. A study demonstrating the effect of I. obliquus polysacharides in cats has shown to be promising, where inhibition of RNA viruses and DNA viruses was observed [320]. This mushroom inhibited viral-induced membrane fusion, and could act against the early stages of HSV viral infection. The aqueous extracts of I. obliquus could prevent HSV-1 entry by directly acting on viral glycoproteins, which in turn prevent membrane fusion [321]. With a host of accomplishments against various reputed viruses, IO does stand a chance against COVID, yet has a long way to go.

Spike protein and the main proteases of SARS-CoV-2 have been identified as potential therapeutic targets and their inhibition may hold the key. Nothing specific is available to treat SARS-CoV-2. Authors have established the therapeutic potential of cordycepin against COVID-19 as a conventional therapeutic strategy. Using in silico studies, the molecular interactions and potential binding affinity of cordycepin with SARS-CoV-2 target proteins were studied. Cordycepin is under clinical trial (NCT00709215). Attempts are being made to see if cordycepin can destabilize SARS-CoV-2 RNAs by inhibiting the polyadenylation process. This can inhibit viral replication and eventual multiplication within the host [322]. It is reported that cordycepin showed strong binding affinity with SARS-CoV-2 spike protein and main proteases that further corroborate therapeutic potential against COVID19. Cordycepin has both pre-clinical and clinical information about antiviral activities; therefore, it is necessary that the global community tests its efficacy and safety against COVID-19. C. sinensis and C. militaris possess antiviral, immunomodulatory, and lung function protective effects, which can also be applicable for COVID-19 treatment. C. sinensis increased tolerance to hypoxia in the lungs by increasing Nrf2 and HIF1 $\alpha$ and decreasing NFKB in vitro. It also increased the anti-inflammatory cytokine TGF- $\beta$ [323]. C. militaris has an immune-enhancing effect in healthy mice and an immune-inhibitory effect in H1N1 (A/Korea/01/2009 (K/09))-infected mice. People infected with COVID-19 have high titers of inflammatory cytokines, which confirms that the lentinan polysaccharide from L. edodes [324] and the acidic polysaccharide (APS) of C. militaris should be given more attention in the fight against SARS-CoV-2. Figure 3 displays the anti-COVID-19 impacts and prospects of mushroom polysaccharides.

Clinical studies confirm the fact that $\beta$-glucans can reduce a series of symptoms of the respiratory apparatus caused by various infections, as well as the fact that they can lower systolic and diastolic artery blood pressure. It is well-known that the symptoms caused by the COVID-19 infection are severe, and studies have shown alleviation of symptoms and considerable improvement of the patient's state following administration of $\beta$-glucans, particularly in most vulnerable cases within ICUs. This supports the fact that oral administration of $\beta$-glucans could be an efficient and inexpensive way to support the immune system of COVID-19-infected patients. However, this would require clinical 
confirmation G. lucidum to be well-known for its antitumoral, antiviral, anti-inflammatory qualities. Ganoderma is one of the most widely used in studies on antiviral qualities; it has been tested against the HIV 1 virus [287]. Table 2 consolidates the antiviral reports of mushroom polysacchraides.

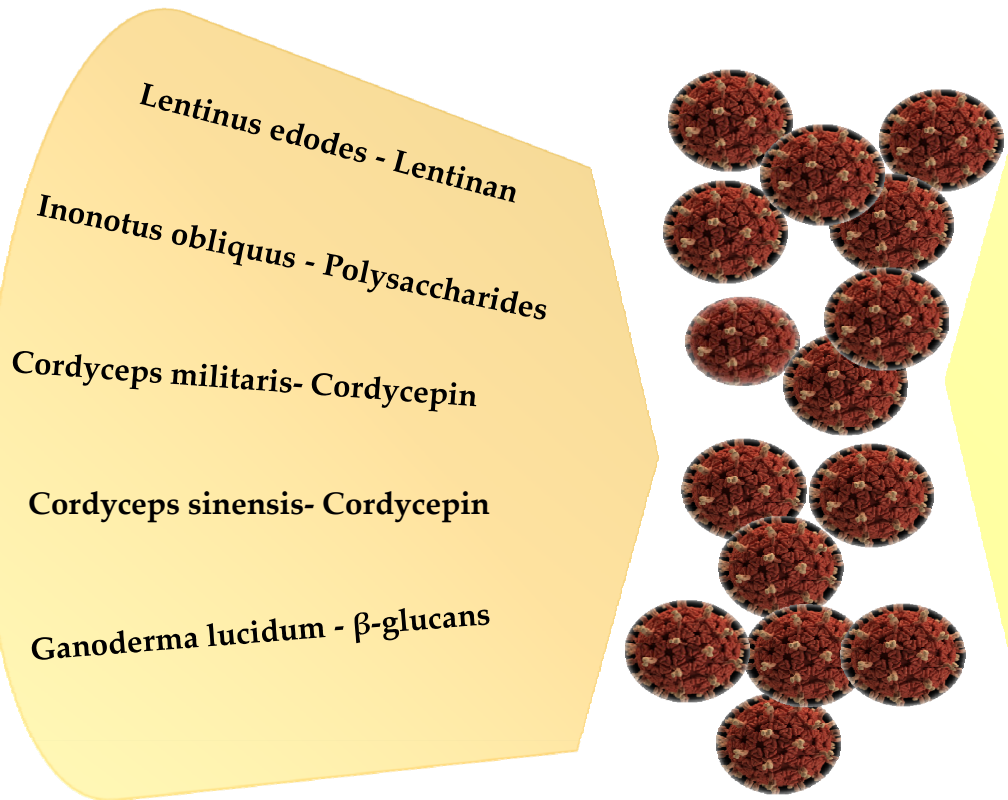

Downregulation of pro-inflammatory
cytokines - TNF- $\alpha$, IL- 2 and IL-11
Upregulating the expressions of IFN-1
and IFN- $\gamma$

Inhibiting cytokine storm

Immunomodulatory effects

Antiproliferative

Antioxidant, anti-inflammatory

Reduce respiratory symptoms

Figure 3. AntiCOVID-19 impacts of mushroom polysaccharides.

Non-digestible carbohydrates with prebiotic effect, such as $\beta$-glucan polysaccharides from medicinal mushrooms, stimulate growth of gut microbes that are favorable to the host's health and spur on the production of SCFA, which energizes anaerobic gut microbes and suppresses pathogens (e.g., Salmonella sp.) and improves host immunity [325,326]. In this way, mushroom polysaccharides can indirectly help patients therapeutically in the struggle against COVID-19 [327-329]. Additionally, with the fact that mushrooms are accomplished for their antibacterial activity, mushrooms can surely aid in the control of bacterial secondary infection (which in the second wave of COVID-19) led to high mortality. There is definitely room for input from antibacterial mushroom extracts and polysaccharides, from various angles, which needs to be incorporated positively.

Table 2. Antiviral activity of mushroom/mushroom polysaccharides,

\begin{tabular}{|c|c|c|c|c|}
\hline Mushroom & Bioactive Component & $\begin{array}{c}\text { Antiviral Activity } \\
\text { against }\end{array}$ & IC50/CC50 Values & Reference \\
\hline Lentinus edodes & $\begin{array}{l}\text { Mannoglucan, } \\
\text { polysaccharide-protein } \\
\text { complex, glucan, lentinan }\end{array}$ & HSV-1; HNV & $\begin{array}{l}\text { IC50: } 26.69 \mathrm{mg} \cdot \mathrm{mL}^{-1} \\
\text { to } 35.12 \mathrm{mg} \cdot \mathrm{mL}^{-1}\end{array}$ & [295] \\
\hline Grifola frondosa & $\begin{array}{l}\text { Proteoglycan, glucan, } \\
\text { galatomannan, } \\
\text { heteroglycan, and } \\
\text { grifolan }\end{array}$ & Enterovirus 71, HSV-1 & Unspecified & [283] \\
\hline Flammulina velutipes & $\begin{array}{l}\text { Glucan-protein complex, } \\
\text { glycoprotein }\end{array}$ & $\begin{array}{l}\text { Antitumor, } \\
\text { anti-inflammatory, } \\
\text { antiviral, } \\
\text { immunomodulating }\end{array}$ & Unspecified & [40] \\
\hline Coriolus versicolor & $\begin{array}{l}\text { Polysaccharides PSK and } \\
\text { PSP }\end{array}$ & $\begin{array}{l}\text { Antiviral effect on HIV } \\
\text { and cytomegalovirus } \\
\text { in vitro and anticancer }\end{array}$ & $6.25-150 \mu \mathrm{g} \mathrm{mL}^{-1}$ & [330] \\
\hline
\end{tabular}


Table 2. Cont.

\begin{tabular}{|c|c|c|c|c|}
\hline Mushroom & Bioactive Component & $\begin{array}{l}\text { Antiviral Activity } \\
\text { against }\end{array}$ & IC50/CC50 Values & Reference \\
\hline $\begin{array}{l}\text { Daedaleopsis confragosa, Datronia } \\
\text { mollis, Ganoderma valesiacum, Irpex } \\
\text { lacteus, Ischnoderma benzoinum, } \\
\text { Laricifomes officinalis, Lenzites betulina, } \\
\text { Phellinus concha-tus, Piptoporus } \\
\text { betulinus, Trametes gibbosa, and } \\
\text { Trametes versicolor }\end{array}$ & Mushroom extracts & $\begin{array}{l}\text { A/chicken/ kurgan/05/2 } \\
\text { (H5N1) bird virus and } \\
\text { the A/Aichi/2/68 } \\
\text { (H3N2)human virus }\end{array}$ & $\begin{array}{l}005 \\
\text { Unspecified }\end{array}$ & [277] \\
\hline Pleurotus pulmonarius & Mushroom water extracts & $\begin{array}{l}\text { A/California/07/09 } \\
\text { (H1N1pdm) }\end{array}$ & CC50: $1.7-8$ & [278] \\
\hline Pleurotus tuber-regium & $\beta$-glucans & $\begin{array}{l}\text { Herpes simplex virus } \\
\text { type } 1 \text { (HSV-1), herpes } \\
\text { simplex virus type } 2 \\
\text { (HSV-2), respiratory } \\
\text { syncytial virus (RSV) } \\
\text { and influenza A virus } \\
\text { (Flu A) }\end{array}$ & IC50: $3.3-6.8 \mu \mathrm{g} \mathrm{mL}^{-1}$ & [279] \\
\hline $\begin{array}{l}\text { Boletus edulis, Lentinus edodes and } \\
\text { Pleurotus ostreatus }\end{array}$ & $\begin{array}{l}\text { Water and methanolic } \\
\text { mushroom extracts }\end{array}$ & $\begin{array}{l}\text { Herpes simplex type } 1 \\
(\text { HSV-1) }\end{array}$ & $\begin{array}{l}\text { IC50: } 26.69 \mathrm{mg} \mathrm{mL}^{-1} \\
\text { to } 35.12 \mathrm{mg} \cdot \mathrm{mL}^{-1}\end{array}$ & [280] \\
\hline Agaricus brasiliensis & Polysaccharide & Type 1 poliovirus & $\begin{array}{l}\text { IC50: } 97.2-922.9 \mu \mathrm{g} \\
\mathrm{mL}^{-1}\end{array}$ & [281] \\
\hline Grifola frondosa & Mushroom extracts & $\begin{array}{l}\text { Enterovirus } 71 \text { and } \\
\text { HSV-1 }\end{array}$ & IC50: $4.1 \mu \mathrm{g} / \mathrm{mL}$ & {$[282,283]$} \\
\hline Inonotus obliquus & Mushroom extracts & Hepatitis C virus & TCD50: $6.0 \mathrm{lg} / \mathrm{mL}$ & [284] \\
\hline Pleurotus sp. and Lentinus sp. & $\begin{array}{l}\text { Methanolic mushroom } \\
\text { extracts }\end{array}$ & $\begin{array}{l}\text { Cytomegalovirus } \\
\text { (HCMV) }\end{array}$ & $\begin{array}{l}\text { IC50: } 180 \mu \mathrm{g} / \mathrm{mL} \text { and } \\
160 \mu \mathrm{g} / \mathrm{mL}\end{array}$ & [285] \\
\hline Pleurotus ostreatus & $\beta$-glucans & Influenza virus & $\begin{array}{l}\text { IC50: } 26.69 \mathrm{mg} \cdot \mathrm{mL}^{-1} \\
\text { to } 35.12 \mathrm{mg} \cdot \mathrm{mL}^{-1}\end{array}$ & [280] \\
\hline Ganoderma lucidum & $\begin{array}{l}\text { Ganolucidic acid A, } \\
3 \beta-5 \alpha \text {-Dihydroxy-6 } 6- \\
\text { Methoxyergosta-7,22- } \\
\text { Diene,ganoderic acid } \\
\text { A-C, Ganoderic acid } \beta \text {, } \\
\text { Ganodermanondiol, } \\
\text { Ganodermanontriol and } \\
\text { Lucidumol B }\end{array}$ & $\begin{array}{l}\text { Inhibits HIV-1 protease } \\
\text { activity }\end{array}$ & IC50: $0.17-0.23 \mathrm{mM}$ & [287-289] \\
\hline Ganoderma colosum & $\begin{array}{l}\text { Colossolactones, } \\
\text { ganomycin I, and } \\
\text { ganomycin B }\end{array}$ & $\begin{array}{l}\text { Anti-HIV-1 protease } \\
\text { activity }\end{array}$ & IC50: $5-39 \mu \mathrm{g} / \mathrm{mL}$ & {$[290,291]$} \\
\hline Ganoderma sinnense & $\begin{array}{l}\text { Ganoderic acid GS-2, } \\
\text { 20-hydroxylucidenic acid } \\
\text { N, 20(21)- } \\
\text { dehydrolucidenicacid N } \\
\text { and ganoderiol F }\end{array}$ & $\begin{array}{l}\text { Anti-HIV-1 protease } \\
\text { activity }\end{array}$ & IC50: $22-116 \mu \mathrm{M}$ & {$[290,291]$} \\
\hline Lignosus rhinocerus & $\begin{array}{l}\text { Crude mushroom } \\
\text { extracts }\end{array}$ & $\begin{array}{l}\text { Anti-HIV-1 protease } \\
\text { activity }\end{array}$ & Unspecified & [292] \\
\hline Auricularia polytricha & $\begin{array}{l}\text { Ergosterol, linoleic acid } \\
\text { and two triacylglycerols }\end{array}$ & $\begin{array}{l}\text { Anti-HIV-1 protease } \\
\text { activity }\end{array}$ & $\begin{array}{l}\text { IC50: } 0.80 \pm 0.08 \\
\mathrm{mg} / \mathrm{mL}\end{array}$ & [292] \\
\hline Cordycep militaris & Arabinogalactan (APS) & $\begin{array}{l}\text { Anti-HIV-1 protease } \\
\text { activity }\end{array}$ & Unspecified & [297] \\
\hline Russula paludosa & $4.5 \mathrm{kDa}$ protein & $\begin{array}{l}\text { Anti-HIV-1 protease } \\
\text { activity }\end{array}$ & $\mathrm{IC} 50=0.25 \mathrm{mg} / \mathrm{mL}$ & [293] \\
\hline
\end{tabular}


Table 2. Cont.

\begin{tabular}{|c|c|c|c|c|}
\hline Mushroom & Bioactive Component & $\begin{array}{c}\text { Antiviral Activity } \\
\text { against }\end{array}$ & IC50/CC50 Values & Reference \\
\hline $\begin{array}{l}\text { Cordycep sinensis and Cordycep } \\
\text { militaris }\end{array}$ & cordycepin & Anti-HIV-1 & Unspecified & {$[296,297]$} \\
\hline Cordycep militaris & cordycepin & $\begin{array}{l}\text { DBA } / 2 \text { mice infected } \\
\text { with } \mathrm{H} 1 \mathrm{~N} 1\end{array}$ & Unspecified & [232] \\
\hline Cordycep militaris & $\begin{array}{l}\text { Acidic polysaccharides } \\
\text { (APS) }\end{array}$ & Anti-influenza & Unspecified & [324] \\
\hline Cordycep militaris & Cordycepin & Anti-Hepatitis C Virus & Unspecified & [294] \\
\hline Grifola frondosa & $\beta$-glucan & $\begin{array}{l}\text { Inhibit in vitro } \\
\text { replication of HSV } \\
\text { type } 1\end{array}$ & $4.1 \mu \mathrm{g} / \mathrm{ml}$ & [306] \\
\hline Grifola frondosa & Protein extract & Hepatitis B virus & $\begin{array}{l}0.59 \mathrm{mg} / \mathrm{mL} \text { and } 1399 \\
\mathrm{IU} / \mathrm{ml}\end{array}$ & [306] \\
\hline $\begin{array}{l}\text { Pleurotus columbinus, Pleurotus } \\
\text { sajor-caju, and Agaricus bisporus }\end{array}$ & Mushroom extracts & Ad7 and HSV2 viruses & Unspecified & [307] \\
\hline Grifola frondosa & $\begin{array}{l}\text { D-fraction from Grifola } \\
\text { frondosa (GF-D) }\end{array}$ & Anti HIV & $\begin{array}{l}0.59 \mathrm{mg} / \mathrm{mL} \text { and } 1399 \\
\mathrm{IU} / \mathrm{ml}\end{array}$ & [301] \\
\hline Lentinus edodes & Lentinan & $\begin{array}{l}\text { Hematopoietic necrosis } \\
\text { virus (IHNV) }\end{array}$ & Unspecified & [314] \\
\hline $\begin{array}{l}\text { Pan cyanescens, Pan natalensis, Pan } \\
\text { cubensis and Pan A+ strain }\end{array}$ & $\begin{array}{l}\text { Hot water mushroom } \\
\text { extracts }\end{array}$ & $\begin{array}{l}\text { Anti Cox sackievirus } \\
(\mathrm{COX}-2)\end{array}$ & Unspecified & [303-306] \\
\hline Inonotus obliquus & Aqueous extract & HSV & $3.82 \mu \mathrm{g} / \mathrm{mL}$ & [319] \\
\hline Lentinus edodes & Lentinan & SARS-CoV-2 & Unspecified & [324] \\
\hline Lentinus edodes & Lentinan & Anti-COVID-19 & Unspecified & [329] \\
\hline Inonotus obliquus & Polysaccharides & SARS-CoV-2 virus & Unspecified & [324] \\
\hline Cordycep militaris & Cordycepin & $\begin{array}{l}\text { Anti } \\
\text { SARS/Anti-COVID-19 }\end{array}$ & Unspecified & {$[323,324]$} \\
\hline Cordycep sinensis & Cordycepin & $\begin{array}{l}\text { Anti } \\
\text { SARS/Anti-COVID-19 }\end{array}$ & Unspecified & {$[323,324]$} \\
\hline
\end{tabular}

\section{What Is and What Is to Be}

The role and explicit benefits from mushroom and mushroom polysaccharides were exploited by the ancients and this has extended to this day. As reviewed, mushrooms encompass bioactivities and unique properties and remedies that are sought after in the medical realm. The natural origin of these bioproducts in mushrooms is an added advantage. As overviewed in this paper, there is no question regarding the numerous versatile benefits that mushrooms yield. Mushrooms have come a long way and have impacted human health and wellbeing and have been there in our hearts and in our diets. Therefore, we are far still from clinical validation of these important nutrient reservoirs. Despite all the known fact files of the potentials of mushrooms, mushroom consumption is still localized to specific geographical zones. Additionally, the popular medicinal mushroom varieties are unavailable in most parts of the world. The local markets mostly are confined to button mushrooms. While the production areas are confined to the UK, Germany, Hungary, Italy, France, the consumption of varied varieties is confined to Japan, China, Korea, Taiwan, Netherlands. There is definitely a need for the sensitization of the fact that medicinal mushrooms need to be cultivated and promoted and consumed, in order to harness the full potential of this valuable natural resource. This is something that this review would like to emphasize. The mode of action/mechanism behind the bioactivity and antiviral 
activity of mushroom polysaccharides is far from elucidated. This review points out to the need to improve in this aspect. Understanding the fundamental modulus operandi of a bioactive material makes room for manipulation of the related aspects of components that ideally hold a position to impact their biological activity.

Mushrooms and their anti-cancer, hepato properties, antibacterial properties, antiviral properties are all known. Mushrooms applied to antiCOVID-19 research are very sparsely reported; this is another area that this review points towards for more awareness and focus. Mushroom polysaccharides are another crucial factor this review has brought up. The antioxidant activities of mushroom polysaccharides, as well as their numerous biological applications, including antibacterial and antiviral properties, have been highlighted. Mushroom polysaccharides have been scarcely highlighted. With the known facts regarding their versatility, this review calls for attention on the area of mushroom polysaccharide research. Additionally, we project a concern, which needs to be looked into-how much of these polysaccharides we are losing during our cleaning process, prior to cooking. This is an aspect this review is critical about. With many water-soluble polysaccharides and extracellular polysaccharides around, the compromises that the processing food industry and domestic cooking processes are making, leading to the loss of this valuable component, are worth probing. Biologically active polysaccharides are widespread among higher basidiomycetous mushrooms, and most of them have unique structures in different species. These polysaccharides have different compositions, most belonging to the group of -d-glucans; these have -(1-3) linkages in the main chain of glucan and additional -(1-6) branch points. High molecular weight glucans apparently seem to be more effective than those of low molecular weight. Moreover, different strains can produce polysaccharides with different properties. For example, the proteoglycan Krestin was developed in Japan from the strain Trametes (Coriolus) versicolor CM-101, whereas a polysaccharide-peptide (PSP) in China was developed in submerged culture from the Cov-1 strain of the same species [330].

With the known importance of mushroom polysaccharides, amplifying the genes that govern biosynthesis of mushroom polysaccharides using molecular engineering can be a very resourceful direction [331]. Chai et al. [332] demonstrated overproduction of $\beta$-glucans in Pleurotus ostreatus mushrooms by promoter engineering. The promoter for the $1,3-\beta$-glucan synthase gene was replaced by the promoter of glyceraldehyde-3-phosphate dehydrogenase gene of Aspergillus nidulans, leading to enhanced $\beta$-glucan yield compared to the wild type. Ji et al. [333] improved polysaccharide production by bioengineering the biosynthetic pathway in Ganoderma lucidum. Overexpression of the homologous UDP glucose phosphoglucomutasegene leads to near doubling of the intracellular and extracellular polysaccharides contrasted to wild type. Meng et al. [208] used the Viteoscilla hemoglobin gene to increase extracellular and intracellular polysaccharides in G. lucidum [334]; amplification of these genes might induce the formation of high-polysaccharide mushrooms [334]. Khan et al. [335] reported that irradiation with $50 \mathrm{k}$ Gy doses induced bond cleavage, enhanced antioxidant activity and increased functional properties. Except for these pioneering reports on the potential of gene manipulation to enhance the production of polysaccharides, successful implementation of antioxidants' mushroom polysaccharide still remains insufficiently explored. There is so much that is known and has been established, yet we are so far from practical implementation. This is something that we highlight as a future perspective in this area. Mushroom culturing needs expansion and awareness regarding the right choice of mushrooms that need to be propagated. Most of the culturing techniques are the age-old methods; the rightful improvisations with culture techniques that may promote and accelerate polysaccharide production, are grey areas, which when worked upon can extend the full exploitation of this resource.

\section{Conclusions}

The bioactivity of mushrooms with specificity to mushroom polysaccharides has been reviewed. The antioxidant properties of mushroom polysaccharides and their antioxidant 
mechanisms have been discussed. The need to extrapolate the existing beneficial attributes into the current pandemic scenario has been emphasized. Mushrooms as a natural remedy for COVID-19 are still inadequately addressed. This review discusses the lacunae in this area of research and highlights aspects that need attention. When the world is looking for answers to the COVID-19 pandemic, we might have some valuable help just in the area of mushrooms.

Author Contributions: Conceptualization, writing — original draft preparation, writing-review and editing, M.M., J.G.; supervision, funding acquisition, S.C. All authors have read and agreed to the published version of the manuscript.

Funding: This research received no external funding.

Acknowledgments: This research was supported by Konkuk Research Fund 2018.

Conflicts of Interest: The authors declare no conflict of interest.

\section{References}

1. Chang, S.-T.; Miles, P.G. Mushrooms: Cultivation, Nutritional Value, Medicinal Effect, and Environmental Impact, 2nd ed.; CRC Press: Boca Raton, FL, USA, 2008.

2. Ergönül, P.G.; Akata, I.; Kalyoncu, F.; Ergönül, B. Fatty acid compositions of six wild edible mushroom species. Sci. World J. 2013, 2013, 163964. [CrossRef]

3. Kosanić, M.; Ranković, B.; Rančić, A.; Stanojković, T. Evaluation of metal concentration and antioxidant, antimicrobial, and anticancer potentials of two edible mushrooms Lactarius deliciosus and Macrolepiota procera. J. Food Drug Anal. 2016, 24, 477-484. [CrossRef]

4. Ruthes, A.C.; Smiderle, F.R.; Iacomini, M. Mushroom heteropolysaccharides: A review on their sources, structure and biological effects. Carbohydr. Polym. 2016, 136, 358-375. [CrossRef]

5. Elsayed, E.A.; El Enshasy, H.; Wadaan, M.A.M.; Aziz, R. Mushrooms: A potential natural source of anti-inflammatory compounds for medical applications. Mediat. Inflamm. 2014, 2014, 805841. [CrossRef] [PubMed]

6. Jayakumar, T.; Thomas, P.A.; Sheu, J.R.; Geraldine, P. In-vitro and in-vivo antioxidant effects of the oyster mushroom Pleurotus ostreatus. Food Res. Int. 2011, 44, 851-861. [CrossRef]

7. Aida, F.M.N.A.; Shuhaimi, M.; Yazid, M.; Maaruf, A.G. Mushroom as a potential source of prebiotics: A review. Trends Food Sci. Technol. 2009, 20, 567-575. [CrossRef]

8. Patel, S.; Goyal, A. Recent developments in mushrooms as anticancer therapeutics: A review. 3 Biotech 2012, 2, 1-15. [CrossRef]

9. Heleno, S.A.; Barros, L.; Sousa, M.J.; Martins, A.; Ferreira, I.C.F.R. Tocopherols composition of Portuguese wild mushrooms with antioxidant capacity. Food Chem. 2010, 119, 1443-1450. [CrossRef]

10. Mattila, P.; Konkö, K.; Eurola, M.; Eurola, M.; Pihlava, J.-M.; Astola, J.; Vahteristo, L.; Hietaniemi, V.; Kumpulainen, J.; Valtonen, M.; et al. Contents of vitamins, mineral elements, and some phenolic compounds in cultivated mushrooms. J. Agric. Food Chem. 2001, 49, 2343-2348. [CrossRef]

11. Barros, L.; Baptista, P.; Correia, D.M.; Casal, S.; Oliveira, B.; Ferreira, I.C.F.R. Fatty acid and sugar compositions, and nutritional value of fve wild edible mushrooms from Northeast Portugal. Food Chem. 2007, 105, 140-145. [CrossRef]

12. Barros, L.; Correia, D.M.; Ferreira, I.C.F.R.; Baptista, P.; Santos-Buelga, C. Optimization of the determination of tocopherols in Agaricus sp. edible mushrooms by a normal phase liquid chromatographic method. Food Chem. 2008, 110, 1046-1050. [CrossRef]

13. Ferreira, I.C.F.R.; Barros, L.; Abreu, R.M.V. Antioxidants in wild mushrooms. Curr. Med. Chem. 2009, 16, 1543-1560. [CrossRef] [PubMed]

14. Pereira, E.; Barros, L.; Martins, A.; Ferreira, I.C.F.R. Towards chemical and nutritional inventory of Portuguese wild edible mushrooms in different habitats. Food Chem. 2012, 130, 394-403. [CrossRef]

15. Vaz, J.A.; Heleno, S.A.; Martins, A.; Almeida, G.M.; Vasconcelos, M.H.; Ferreira, I.C.F.R. Wild mushrooms Clitocybe alexandri and Lepista inversa: In vitro antioxidant activity and growth inhibition of human tumour cell lines. Food Chem. Toxicol. 2010, 48, 2881-2884. [CrossRef] [PubMed]

16. Ferreira, I.C.F.R.; Vaz, J.A.; Vasconcelos, M.H.; Martins, A. Compounds from wild mushrooms with antitumor potential. AntiCancer Agents Med. Chem. 2010, 10, 424-436. [CrossRef]

17. Chang, S.-T.; Wasser, S.P. The role of culinary-medicinal mushrooms on human welfare with a pyramid model for human health. Int. J. Med. Mushrooms 2012, 14, 95-134. [CrossRef] [PubMed]

18. Finimundy, T.; Gambato, G.; Fontana, R.; Camassola, M.; Salvador, M.; Moura, S.; Hess, J.; Henriques, J.; Dillon, A.; Roesch-Ely, M. Aqueous extracts of Lentinula edodes and Pleurotus sajor-caju exhibit high antioxidant capability and promising in vitro antitumor activity. Nutr. Res. 2013, 33, 76-84. [CrossRef]

19. Yu, S.; Weaver, V.; Martin, K.; Cantorna, M.T. Te effects of whole mushrooms during inflammation. BMC Immunol. 2009, 10, 12. [CrossRef] 
20. Zhang, L.; Fan, C.; Liu, S.; Zang, Z.; Jiao, L. Chemical composition and antitumor activity of polysaccharide from Inonotus obliquus. J. Med. Plants Res. 2011, 5, 1251-1260.

21. Chen, J.; Seviour, R. Medicinal importance of fungal $\beta-(1 \rightarrow 3),(1 \rightarrow 6)$-glucans. Mycol. Res. 2007, 111, 635-652. [CrossRef]

22. Brown, A.C.; Waslien, C.I. Stress and nutrition. In Encyclopedia of Food Sciences and Nutrition; Trugo, L., Finglas, P.M., Eds.; Academic Press: London, UK, 2003.

23. Carneiro, A.A.J.; Ferreira, I.C.F.R.; Dueñas, M.; Barros, L.; da Silva, R.; Gomes, E.; Santos-Buelga, C. Chemical composition and antioxidant activity of dried powder formulations of Agaricus blazei and Lentinus edodes. Food Chem. 2013, 138, $2168-2173$. [CrossRef] [PubMed]

24. Kim, H.G.; Yoon, D.H.; Lee, W.H.; Han, S.K.; Shrestha, B.; Kim, C.H.; Lim, M.H.; Chang, W.; Lim, S.; Choi, S.; et al. Phellinus linteus inhibits inflammatory mediators by suppressing redox-based NF- $\mathrm{KB}$ and MAPKs activation in lipopolysaccharide-induced RAW 264.7 macrophage. J. Ethnopharmacol. 2007, 114, 307-315. [CrossRef] [PubMed]

25. Sarikurkcu, C.; Tepe, B.; Yamaç, M. Evaluation of the antioxidant activity of four edible mushrooms from the Central Anatolia, Eskisehir-Turkey: Lactarius deterrimus, Suillus collitinus, Boletus edulis, Xerocomus chrysenteron. Bioresour. Technol. 2008, 99, 6651-6655. [CrossRef]

26. Synytsya, A.; Mícková, K.; Synytsya, A.; Jablonský, I.; Spěváček, J.; Erban, V.; Kováříková, E.; Čopíková, J. Glucans from fruit bodies of cultivated mushrooms Pleurotus ostreatus and Pleurotus eryngii: Structure and potential prebiotic activity. Carbohydr. Polym. 2009, 76, 548-556. [CrossRef]

27. Wang, Z.; Luo, D.; Liang, Z. Structure of polysaccharides from the fruiting body of Hericium erinaceus Pers. Carbohydr. Polym. 2004, 57, 241-247. [CrossRef]

28. Flegg, P.B.; Maw, G. Mushrooms and their possible contribution to the world. Mushroom J. 1997, 48, $395-403$.

29. Gruen, F.H.; Wong, M.W. Distribution of cellular amino acids, proteins and total nitrogen during fruit body development in Flammuling velutipes. Can. J. Bot. 1982, 160, 1339-1341.

30. Kalac, P. A review of chemical composition and nutritional value of wild-growing and cultivated mushrooms. J. Sci. Food Agric. 2013, 93, 209-218. [CrossRef]

31. Reis, F.S.; Barros, L.; Martins, A.; Ferreira, I.C.F.R. Chemical composition and nutritional value of the most widely appreciated cultivated mushrooms: An inter-species comparative study. Food Chem. Toxicol. 2012, 50, 191-197. [CrossRef]

32. Mattila, P.; Salo-Väänänen, P.; Könkö, K.; Aro, H.; Jalava, T. Basic composition and amino acid contents of mushrooms cultivated in Finland. J. Agric. Food Chem. 2002, 50, 6419-6422. [CrossRef]

33. Mdachi, S.J.M.; Nkunya, M.H.H.; Nyigo, V.A.; Urasa, I.T. Amino acid composition of some Tanzanian wild mushrooms. Food Chem. 2004, 86, 179-182. [CrossRef]

34. Ouzouni, P.K.; Petridis, D.; Koller, W.-D.; Riganakos, K.A. Nutritional value and metal content of wild edible mushrooms collected from West Macedonia and Epirus, Greece. Food Chem. 2009, 115, 1575-1580. [CrossRef]

35. Ribeiro, B.; de Pinho, P.G.; Andrade, P.; Baptista, P.; Valentão, P. Fatty acid composition of wild edible mushrooms species: A comparative study. Microchem. J. 2009, 93, 29-35. [CrossRef]

36. Erjavec, J.; Kos, J.; Ravnikar, M.; Dreo, T.; Sabotic, J. Proteins of higher fungi-From forest to application. Trends Biotechnol. 2012, 30, 259-273. [CrossRef]

37. Wang, X.-M.; Zhang, J.; Wu, L.-H.; Zhao, Y.-L.; Li, T.; Li, J.-Q.; Wang, Y.-Z.; Liu, H.-G. A mini-review of chemical composition and nutritional value of edible wildgrown mushroom from China. Food Chem. 2014, 151, 279-285. [CrossRef]

38. Wasser, S.P. Current findings, future trends, and unsolved problems in studies of medicinal mushrooms. Appl. Microbiol. Biotechnol. 2011, 89, 1323-1332. [CrossRef] [PubMed]

39. Heleno, S.A.; Barros, L.; Martins, A.; Queiroz, M.J.R.P.; Santos-Buelga, C.; Ferreira, I.C.F.R. Phenolic, polysaccharidic, and lipidic fractions of mushrooms from northeastern portugal: Chemical compounds with antioxidant properties. J. Agric. Food Chem. 2012, 60, 4634-4640. [CrossRef]

40. Zhang, M.; Cui, S.W.; Cheung, P.C.K.; Wang, Q. Antitumor polysaccharides from mushrooms: A review on their isolation process, structural characteristics and antitumor activity. Trends Food Sci. Technol. 2007, 18, 4-19. [CrossRef]

41. Wasser, S. Medicinal mushrooms as a source of antitumor and immunomodulating polysaccharides. Appl. Microbiol. Biotechnol. 2002, 60, 258-274.

42. Klis, F.M.; De Groot, P.; Hellingwerf, K. Molecular organization of the cell wall of Candida albicans. Med. Mycol. 2001, 39, 1-8. [CrossRef]

43. Fortes, R.C.; Recôva, V.L.; Melo, A.L.; Novaes, M.R.C.G. Effects of dietary supplementation with medicinal fungus in fasting glycemia levels of patients with colorectal cancer: A randomized, double-blind, placebo-controlled clinical study. Nutr. Hosp. 2008, 23, 591-598.

44. Shaffique, S.; Kang, S.-M.; Kim, A.-Y.; Imran, M.; Khan, M.A.; Lee, I.-J. Current knowledge of medicinal mushrooms related to anti-oxidant properties. Sustainability 2021, 13, 7948. [CrossRef]

45. Ren, L.; Perera, C.; Hemar, Y. Antitumor activity of mushroom polysaccharides: A review. Food Funct. 2012, 3, 1118-1130. [CrossRef] [PubMed]

46. Fortes, R.C.; Novaes, M.R.C.G. The effects of Agaricus sylvaticus fungi dietary supplementation on the metabolism and blood pressure of patients with colorectal cancer during post surgical phase. Nutr. Hosp. 2011, 26, 176-186. 
47. Deng, G.; Lin, H.; Seidman, A.; Fornier, M.; D’Andrea, G.; Wesa, K.; Yeung, S.; Cunningham-Rundles, S.; Vickers, A.J.; Cassileth, B. A phase I/II trial of a polysaccharide extract from Grifola frondosa (Maitake mushroom) in breast cancer patients: Immunological effects. J. Cancer Res. Clin. Oncol. 2009, 135, 1215-1221. [CrossRef]

48. Okuno, K.; Uno, K. Efficacy of orally administered Lentinula edodes mycelia extract for advanced gastrointestinal cancer patients undergoing cancer chemotherapy: A pilot study. Asian Pac. J. Cancer Prev. 2011, 12, 1671-1674. [PubMed]

49. Tanigawa, K.; Ito, Y.; Sakai, M.; Kobayashi, Y. Evaluation of quality of life and immune function in cancer patients receiving combined immunotherapy and oral administration of lentinula edodes mycelia extract. Gan Kagaku Ryoho 2012, 39, $1779-1781$.

50. Yamaguchi, Y.; Miyahara, E.; Hihara, J. Efficacy and safety of orally administered lentinula edodes mycelia extract for patients undergoing cancer chemotherapy: A pilot study. Am. J. Chin. Med. 2011, 39, 451-459. [CrossRef]

51. Suzuki, N.; Takimoto, Y.; Suzuki, R.; Arai, T.; Uebaba, K.; Nakai, M.; Strong, J.M.; Tokuda, H. Efficacy of oral administration of Lentinula eododes mycelia extract for breast cancer patients undergoing postoperative hormone therapy. Asian Pac. J. Cancer Prev. 2013, 14, 3469-3472. [CrossRef]

52. Nagashima, Y.; Maeda, N.; Yamamoto, S.; Yoshino, S.; Oka, M. Evaluation of host quality of life and immune function in breast cancer patients treated with combination of adjuvant chemotherapy and oral administration of Lentinula edodes mycelia extract. OncoTargets Ther. 2013, 6, 853-859. [CrossRef]

53. Ina, K.; Kataoka, T.; Ando, T. The use of lentinan for treating gastric cancer. Anticancer Agents Med. Chem. 2013, 13, 681-688. [CrossRef]

54. Valadares, F.; Novaes, M.R.C.G.; Cañete, R. Effect of Agaricus sylvaticus supplementation on nutritional status and adverse events of chemotherapy of breast cancer: A randomized, placebo-controlled, double-blind clinical trial. Indian J. Pharmacol. 2013, 45, 217-222. [CrossRef]

55. Li, J.; Zou, L.; Chen, W.; Zhu, B.; Shen, N.; Ke, J.; Lou, J.; Song, R.; Zhong, R.; Miao, X. Dietary mushroom intake may reduce the risk of breast cancer: Evidence from a meta-analysis of observational studies. PLoS ONE 2014, 9, e93437. [CrossRef]

56. Schwartz, B.; Hadar, Y. Possible mechanisms of action of mushroom-derived glucans on inflammatory bowel disease and associated cancer. Ann. Transl. Med. 2014, 2, 19. [CrossRef] [PubMed]

57. Twardowski, P.; Kanaya, N.; Frankel, P.; Synold, T.; Ms, C.R.; Pal, S.K.; Rn, M.J.; Rn, M.P.; Moore, T.; Tryon, P.; et al. A phase I trial of mushroom powder in patients with biochemically recurrent prostate cancer: Roles of cytokines and myeloid-derived suppressor cells for Agaricus bisporus-induced prostate-specific antigen responses. Cancer 2015, 121, 2942-2950. [CrossRef] [PubMed]

58. Li, Y.H.; Niu, Y.B.; Sun, Y.; Zhang, F.; Liu, C.X.; Fan, L.; Mei, Q.B. Role of phytochemicals in colorectal cancer prevention. World J. Gastroenterol. 2015, 21, 9262-9272. [CrossRef]

59. Friedman, M. Mushroom polysaccharides: Chemistry and antiobesity, antidiabetes, anticancer, and antibiotic properties in cells, rodents, and humans. Foods 2016, 5, 80. [CrossRef] [PubMed]

60. Holmes, D. Obesity: Medicinal mushroom reduces obesity by modulating microbiota. Nat. Rev. Endocrinol. 2015, 11, 504. [CrossRef] [PubMed]

61. Chang, C.-J.; Lin, C.-S.; Lu, C.-C.; Martel, J.; Ko, Y.-F.; Ojcius, D.M.; Tseng, S.-F.; Wu, T.-R.; Chen, Y.-Y.M.; Young, J.D.; et al. Ganoderma lucidum reduces obesity in mice by modulating the composition of the gut microbiota. Nat. Commun. $2015,6,7489$. [CrossRef]

62. Johnson, E.; Førland, D.T.; Sætre, L.; Bernardshaw, S.V.; Lyberg, T.; Hetland, G. Effect of an extract based on the medicinal mushroom agaricus blazei murill on release of cytokines, chemokines and leukocyte growth factors in human blood ex vivo and in vivo. Scand. J. Immun. 2009, 69, 242-250. [CrossRef]

63. Zhu, J.-S.; Halpern, G.M.; Jones, K. The scientific rediscovery of an ancient Chinese herbal medicine: Cordyceps sinensis Part I. J. Altern. Complement. Med. Fall 1998, 4, 289-303. [CrossRef]

64. Jordan, J.; Sullivan, A.; Lee, T. Immune activation by a sterile aqueous extract of cordyceps sinensis: Mechanism of action. Immunopharmacol. Immunotoxicol. 2008, 30, 53-70. [CrossRef] [PubMed]

65. Lull, C.; Wichers, H.J.; Savelkoul, H.F.J. Antiinflammatory and immunomodulating properties of fungal metabolites. Mediat. Inflamm. 2005, 2005, 895272. [CrossRef] [PubMed]

66. Moradali, M.-F.; Mostafavi, H.; Ghods, S.; Hedjaroude, G.-A. Immunomodulating and anticancer agents in the realm of macromycetes fungi (macrofungi). Int. Immunopharmacol. 2007, 7, 701-724. [CrossRef]

67. Enshasy, H.; Hatti-Kaul, R. Mushroom immunomodulators: Unique molecules with unlimited applications. Trends Biotechnol. 2013, 31, 668-677. [CrossRef]

68. Jeong, Y.-T.; Yang, B.-K.; Jeong, S.-C.; Kim, S.-M.; Song, C.-H. Ganoderma applanatum: A promising mushroom for antitumor and immunomodulating activity. Phytother. Res. 2008, 22, 614-619. [CrossRef] [PubMed]

69. Ma, B.; Ren, W.; Zhou, Y.; Ma, J.; Ruan, Y.; Wen, C.-N. Triterpenoids from the spores of Ganoderma lucidum. N. Am. J. Med. Sci. 2011, 3, 495-498. [CrossRef]

70. Su, H.-G.; Peng, X.-R.; Shi, Q.-Q.; Huang, Y.-J.; Zhou, L.; Qiu, M.-H. Lanostane triterpenoids with anti-inflammatory activities from Ganoderma lucidum. Phytochemistry 2020, 173, 112256. [CrossRef]

71. Li, Q.-Z.; Zheng, Y.-Z.; Zhou, X.-W. Fungal immunomodulatory proteins: Characteristic, potential antitumor activities and their molecular mechanisms. Drug Discov. Today 2019, 24, 307-314. [CrossRef] 
72. Sonawane, H.; Bhosle, H.; Bapat, G.; Vikram, G. Pharmaceutical metabolites with potent bioactivity from mushrooms. J. Pharm. Res. 2014, 8, 969-972.

73. Sze, S.; Ho, J.; Liu, W. Volvariella volvacea lectin activates mouse T lymphocytes by a calcium dependent pathway. J. Cell. Biochem. 2004, 92, 1193-1202. [CrossRef] [PubMed]

74. Guggenheim, A.G.; Wright, K.M.; Zwickey, H.L. Immune modulation from five majorMushrooms: Application to integrative oncology. Integr. Med. (Encinitas Calif.) 2014, 13, 32-44.

75. Suwannarach, N.; Kumla, J.; Sujarit, K.; Pattananandecha, T.; Saenjum, C.; Lumyong, S. Natural bioactive compounds from fungi as potential candidates for protease inhibitors and immunomodulators to apply for coronaviruses. Molecules 2020, 25, 1800. [CrossRef] [PubMed]

76. Gunde-Cimerman, N.; Plemenitaš, A.; Cimerman, A. Pleurotus fungi produce mevinolin, an inhibitor of HMG CoA reductase. FEMS Microbiol. Lett. 1993, 111, 333-337. [CrossRef]

77. Hossain, S.; Hashimoto, M.; Choudhury, E.K.; Alam, N.; Hussain, S.; Hasan, M.; Choudhury, S.K.; Mahmud, I. Dietary mushroom (Pleurotus ostreatus) ameliorates atherogenic lipid in hypercholesterolaemic rats. Clin. Exp. Pharmacol. Physiol. 2003, 30, 470-475. [CrossRef]

78. Alves, M.J.; Ferreira, I.F.R.; Dias, J.; Teixeira, V.; Martins, A.; Pintado, M.M. A review on antimicrobial activity of mushroom (Basidiomycetes) extracts and isolated compounds. Planta Med. 2012, 78, 1707-1718. [CrossRef]

79. Kozarski, M.; Klaus, A.; Jakovljevic, D.; Todorovic, N.; Vunduk, J.; Petrović, P.; Niksic, M.; Vrvic, M.M.; Van Griensven, L. Antioxidants of edible mushrooms. Molecules 2015, 20, 19489-19525. [CrossRef] [PubMed]

80. Kozarski, M.; Klaus, A.; Vunduk, J.; Zizak, Z.; Niksic, M.; Jakovljevic, D.; Vrvic, M.M.; Van Griensven, L.J.L.D. Nutraceutical properties of the methanolic extract of edible mushroom Cantharellus cibarius (Fries): Primary mechanisms. Food Funct. 2015, 6, 1875-1886. [CrossRef]

81. Chen, S.-Y.; Ho, K.-J.; Hsieh, Y.-J.; Wang, L.-T.; Mau, J.-L. Contents of lovastatin, $\gamma$-aminobutyric acid and ergothioneine in mushroom fruiting bodies and mycelia. LWT Food Sci. Technol. 2012, 47, 274-278. [CrossRef]

82. Klaus, A.; Kozarski, M.; Niksic, M.; Jakovljevic, D.; Todorovic, N.; Van Griensven, L.J.L.D. Antioxidative activities and chemical characterization of polysaccharides extracted from the basidiomycete Schizophyllum commune. LWT Food Sci. Technol. 2011, 44, 2005-2011. [CrossRef]

83. Klaus, A.; Kozarski, M.; Niksic, M.; Jakovljevic, D.; Todorovic, N.; van Griensven, L.J.L.D.; Stefanoska, I. The edible mushroom Laetiporus sulphureus as potential source of natural antioxidants. Int. J. Food Sci. Nutr. 2013, 64, 599-610. [CrossRef] [PubMed]

84. Kozarski, M.; Klaus, A.; Nikšić, M.; Vrvic, M.; Todorović, N.; Jakovljević, D.; Van Griensven, L.J.L.D. Antioxidative activities and chemical characterization of polysaccharide extracts from the widely used mushrooms Ganoderma applanatum, Ganoderma lucidum, Lentinus edodes and Trametes versicolor. J. Food Compos. Anal. 2012, 26, 144-153. [CrossRef]

85. Kozarski, M.; Klaus, A.; Niksic, M.; Jakovljević, D.; Helsper, J.P.; Van Griensven, L.J. Antioxidative and immunomodulating activities of polysaccharide extracts of the medicinal mushrooms Agaricus bisporus, Agaricus brasiliensis, Ganoderma lucidum and Phellinus linteus. Food Chem. 2011, 129, 1667-1675. [CrossRef]

86. Klaus, A.; Kozarski, M.; Vunduk, J.; Todorovic, N.; Jakovljević, D.; Zizak, Z.; Pavlović, V.; Levic, S.; Niksic, M.; Van Griensven, L.J. Biological potential of extracts of the wild edible Basidiomycete mushroom Grifola frondosa. Food Res. Int. 2015, 67, $272-283$. [CrossRef]

87. Kozarski, M.; Klaus, A.; Jakovljević, D.; Todorovic, N.; Niksic, M.; Vrvic, M.; van Griensven, L.J. Dietary polysaccharide extracts of Agaricus brasiliensis fruiting bodies: Chemical characterization and bioactivities at different levels of purification. Food Res. Int. 2014, 64, 53-64. [CrossRef] [PubMed]

88. Glamočlija, J.; Ciric, A.; Nikolic, M.; Fernandes, Â.; Barros, L.; Calhelha, R.C.; Ferreira, I.C.F.R.; Sokovic, M.; van Griensven, L.J.L.D. Chemical characterization and biological activity of Chaga (Inonotus obliquus), a medicinal "mushroom". J. Ethnopharmacol. 2015, 162, 323-332. [CrossRef]

89. Debnath, T.; Park, D.K.; Lee, B.R.; Jin, H.L.; Lee, S.Y.; Samad, N.B.; Lim, B.O. Antioxidant activity of Inonotus obliquus grown on germinated brown rice extracts. J. Biochem. 2013, 37, 456-464.

90. Nakajima, Y.; Sato, Y.; Konishi, T. Antioxidant small phenolic ingredients in Inonotus obliquus (persoon) Pilat (Chaga). Chem. Pharm. Bull. 2007, 55, 1222-1226. [CrossRef]

91. Reis, F.S.; Martins, A.; Barros, L.; Ferreira, I. Antioxidant properties and phenolic profile of the most widely appreciated cultivated mushrooms: A comparative study between in vivo and in vitro samples. Food Chem. Toxicol. 2012, 50, 1201-1207. [CrossRef] [PubMed]

92. Stojković, D.; Reis, F.S.; Glamočlija, J.; Ćirić, A.; Barros, L.; Van Griensven, L.J.L.D.; Ferreira, I.C.F.R.; Soković, M. Cultivated strains of Agaricus bisporus and A. brasiliensis: Chemical characterization and evaluation of antioxidant and antimicrobial properties for the final healthy product-Natural preservatives in yoghurt. Food Funct. 2014, 5, 1602-1612. [CrossRef]

93. Ker, Y.-B.; Chen, K.-C.; Chyau, C.-C.; Chen, C.-C.; Guo, J.-H.; Hsieh, C.-L.; Wang, H.-E.; Peng, C.-C.; Chang, C.-H.; Peng, R.Y. Antioxidant capability of polysaccharides fractionated from submerge-cultured agaricus blazei mycelia. J. Agric. Food Chem. 2005, 53, 7052-7058. [CrossRef] [PubMed]

94. Lo, T.C.T.; Chang, C.A.; Chiuc, K.H.; Tsayd, P.K.; Jena, J.F. Correlation evaluation of antioxidant properties on the monosaccharide components and glycosyl linkages of polysaccharide with different measuring methods. Carbohydr. Polym. 2011, 86, 320-327. [CrossRef] 
95. Heleno, S.A.; Stojkovic, D.; Barros, L.; Glamočlija, J.; Sokovic, M.; Martins, A.; Queiroz, M.J.; Ferreira, I. A comparative study of chemical composition, antioxidant and antimicrobial properties of Morchella esculenta (L.) Pers. from Portugal and Serbia. Food Res. Int. 2013, 51, 236-243. [CrossRef]

96. Li, W.-J.; Nie, S.-P.; Liu, X.-Z.; Zhang, H.; Yang, Y.; Yu, Q.; Xie, M.-Y. Antimicrobial properties, antioxidant activity and cytotoxicity of ethanol-soluble acidic components from Ganoderma atrum. Food Chem. Toxicol. 2012, 50, 689-694. [CrossRef]

97. Yeh, J.-Y.; Hsieh, L.-H.; Wu, K.-T.; Tsai, C.-F. Antioxidant properties and antioxidant compounds of various extracts from the edible basidiomycete Grifola frondosa (Maitake). Molecules 2011, 16, 3197-3211. [CrossRef] [PubMed]

98. Ajith, T.A.; Janardhanan, K.K. Indian medicinal mushrooms as a source of antioxidant and antitumor agents. J. Clin. Biochem. Nutr. 2007, 40, 157-162. [CrossRef] [PubMed]

99. Liu, W.; Wang, H.; Pang, X.; Yao, W.; Gao, X. Characterization and antioxidant activity of two low-molecular-weight polysaccharides purified from the fruiting bodies of Ganoderma lucidum. Int. J. Biol. Macromol. 2010, 46, 451-457. [CrossRef] [PubMed]

100. Mau, J.-L.; Chao, G.-R.; Wu, K.-T. Antioxidant properties of methanolic extracts from several ear mushrooms. J. Agric. Food Chem. 2001, 49, 5461-5467. [CrossRef] [PubMed]

101. Puttaraju, N.G.; Venkateshaiah, S.U.; Dharmesh, S.M.; Urs, S.M.N.; Somasundaram, R. Antioxidant activity of indigenous edible mushrooms. J. Agric. Food Chem. 2006, 54, 9764-9772. [CrossRef]

102. Shin, K.H.; Lim, S.S.; Lee, S.H.; Lee, Y.S.; Cho, S.Y. Antioxidant and immunostimulating activities of the fruiting bodies of Paecilomyces japonica, a new type of Cordyceps sp.. Ann. N. Y. Acad. Sci. 2006, 928, 261-273. [CrossRef]

103. Song, W.; van Griensven, L.J.L.D. Pro- and antioxidative properties of medicinal mushroom extracts. Int. J. Med. Mushrooms 2008, $10,315-324$.

104. Tseng, Y.-H.; Yang, J.-H.; Mau, J.-L. Antioxidant properties of polysaccharides from Ganoderma tsugae. Food Chem. 2008, 107, 732-738. [CrossRef]

105. Yang, J.-H.; Lin, H.-C.; Mau, J.-L. Antioxidant properties of several commercial mushrooms. Food Chem. 2002, 77, 229-235. [CrossRef]

106. Ferreira, I.C.; Heleno, S.A.; Reis, F.S.; Stojkovic, D.; Queiroz, M.J.; Vasconcelos, M.H.; Sokovic, M. Chemical features of Ganoderma polysaccharides with antioxidant, antitumor and antimicrobial activities. Phytochemistry 2015, 114, 38-55. [CrossRef] [PubMed]

107. Ren, L.; Hemar, Y.; Perera, C.; Lewis, G.; Krissansen, G.W.; Buchanan, P.K. Antibacterial and antioxidant activities of aqueous extracts of eight edible mushrooms. Bioact. Carbohydr. Diet. Fibre 2014, 3, 41-51. [CrossRef]

108. Yu, Y.; Guzha, N.; Ying, T. Extraction of polysaccharide from Ganoderma lucidum assisted ultrafiltration and optimization of free radical scavenging capacity. J. Chin. Inst. Food Sci. Technol. 2014, 34, 40-46.

109. Siu, K.-C.; Chen, X.; Wu, J.-Y. Constituents actually responsible for the antioxidant activities of crude polysaccharides isolated from mushrooms. J. Funct. Foods 2014, 11, 548-556. [CrossRef]

110. Zheng, Y.; Li, Y.; Wang, W.-D. Optimization of ultrasonic-assisted extraction and in vitro antioxidant activities of polysaccharides from Trametes orientalis. Carbohydr. Polym. 2014, 111, 315-323. [CrossRef]

111. Liu, Q.; Tian, G.; Yan, H.; Geng, X.; Cao, Q.; Wang, H.; Ng, T.B. Characterization of polysaccharides with antioxidant and hepatoprotective activities from the wild edible mushroom Russula vinosa Lindblad. J. Agric. Food Chem. 2014, 62, 8858-8866. [CrossRef]

112. Wang, Z.-B.; Pei, J.-J.; Ma, H.-L.; Cai, P.-F.; Yan, J.-K. Effect of extraction media on preliminary characterizations and antioxidant activities of Phellinus linteus polysaccharides. Carbohydr. Polym. 2014, 109, 49-55. [CrossRef]

113. Fu, H.-Y.; Shieh, D.-E.; Ho, C.-T. Antioxidant and free radical scavenging activities of edible mushrooms. J. Food Lipids 2002, 9 , 35-43. [CrossRef]

114. Elmastas, M.; Isildak, O.; Turkekul, I.; Temur, N. Determination of antioxidant activity and antioxidant compounds in wild edible mushrooms. J. Food Compos. Anal. 2007, 20, 337-345. [CrossRef]

115. Bao, H.N.; Osako, K.; Ohshima, T. Value-added use of mushroom ergothioneine as a colour stabilizer in processed fish meats. J. Sci. Food Agric. 2010, 90, 1634-1641. [CrossRef]

116. Cheung, L.; Cheung, P.C.; Ooi, V.E. Antioxidant activity and total phenolics of edible mushroom extracts. Food Chem. 2003, 81, 249-255. [CrossRef]

117. Heleno, S.A.; Barros, L.; Martins, A.; Queiroz, M.J.R.; Santos-Buelga, C.; Ferreira, I.C. Fruiting body, spores and in vitro produced mycelium of Ganoderma lucidum from Northeast Portugal: A comparative study of the antioxidant potential of phenolic and polysaccharidic extracts. Food Res. Int. 2012, 46, 135-140. [CrossRef]

118. Chang, H.Y.; Ho, Y.L.; Sheu, M.J.; Lin, Y.H.; Tseng, M.C.; Wu, S.H.; Huang, G.J.; Chang, Y.S. Antioxidant and free radical scavenging activities of Phellinus merrillii extracts. Bot. Stud. 2007, 48, 407-417.

119. Guo, C.Y.; Ji, S.Z.; Ping, C.X. Modulatory effect of Ganoderma lucidum polysaccharides on serum antioxidant enzymes activities in ovarian cancer rats. Carbohydr. Polym. 2009, 78, 258-262.

120. Ping, C.X.; Yan, C.; Bing, L.S.; Guo, C.Y.; Yun, L.J.; Ping, L.L. Free radical scavenging of Ganoderma lucidum polysaccharides and its effect on antioxidant enzymes and immunity activities in cervical carcinoma rats. Carbohydr. Polym. 2009, 77, 389-393.

121. Jia, J.; Zhang, X.; Hu, Y.-S.; Wu, Y.; Wang, Q.-Z.; Li, N.-N.; Guo, Q.-C.; Dong, X.-C. Evaluation of in vivo antioxidant activities of Ganoderma lucidum polysaccharides in STZ-diabetic rats. Food Chem. 2009, 115, 32-36. [CrossRef]

122. Fan, L.; Zhang, S.; Yu, L.; Ma, L. Evaluation of antioxidant property and quality of breads containing Auricularia auricula polysaccharide flour. Food Chem. 2007, 101, 1158-1163. [CrossRef] 
123. Lee, Y.L.; Jian, S.Y.; Lian, P.Y.; Mau, J.L. Antioxidant properties of extracts from a white mutant of the mushroom Hypsizigus marmoreus. J. Food Comp. Anal. 2008, 21, 116-124. [CrossRef]

124. Mau, J.-L.; Lin, H.-C.; Song, S.-F. Antioxidant properties of several specialty mushrooms. Food Res. Int. 2002, 35, 519-526. [CrossRef]

125. Murcia, M.A.; Martínez-Tomé, M.; Jiménez, A.M.; Vera, A.M.; Honrubia, M.; Parras, P. Antioxidant activity of edible fungi (truffles and mushrooms): Losses during industrial processing. J. Food Prot. 2002, 65, 1614-1622. [CrossRef] [PubMed]

126. Song, Y.S.; Kim, S.-H.; Sa, J.-H.; Jin, C.; Lim, C.-J.; Park, E.-H. Anti-angiogenic, antioxidant and xanthine oxidase inhibition activities of the mushroom Phellinus linteus. J. Ethnopharmacol. 2003, 88, 113-116. [CrossRef]

127. Acharya, K.; Samui, K.; Rai, M.; Dutta, B.B.; Acharya, R. Antioxidant and nitric oxide synthase activation properties of Auricularia auricula. Indian J. Exp. Biol. 2004, 42, 538-540.

128. Mau, J.-L.; Chang, C.-N.; Huang, S.-J.; Chen, C.-C. Antioxidant properties of methanolic extracts from Grifola frondosa, Morchella esculenta and Termitomyces albuminosus mycelia. Food Chem. 2004, 87, 111-118. [CrossRef]

129. Acharya, K.; Yonzone, P.; Rai, M.; Rupa, A. Antioxidant and nitric oxide synthase activation properties of Ganoderma applanatum. Indian J. Exp. Biol. 2005, 43, 926-929.

130. Cheung, L.; Cheung, P.C. Mushroom extracts with antioxidant activity against lipid peroxidation. Food Chem. 2005, 89, 403-409. [CrossRef]

131. Lo, K.; Cheung, P.C. Antioxidant activity of extracts from the fruiting bodies of Agrocybe aegerita var. alba. Food Chem. 2005, 89, 533-539. [CrossRef]

132. Choi, Y.; Lee, S.; Chun, J.; Lee, H.; Lee, J. Influence of heat treatment on the antioxidant activities and polyphenolic compounds of Shiitake (Lentinus edodes) mushroom. Food Chem. 2006, 99, 381-387. [CrossRef]

133. Ribeiro, B.; Rangel, J.; Valentão, P.; Baptista, P.; Seabra, R.M.; Andrade, P.B. Contents of carboxylic acids and two phenolics and antioxidant activity of dried portuguese wild edible mushrooms. J. Agric. Food Chem. 2006, 54, 8530-8537. [CrossRef] [PubMed]

134. Hu, S.H.; Liang, Z.C.; Chia, Y.C.; Lien, J.L.; Chen, K.S.; Lee, M.Y.; Wang, J.C. Antihyperlipidemic and antioxidant effects of extracts from Pleurotus citrinopileatus. J. Agric. Food Chem. 2006, 54, 2103-2110. [CrossRef]

135. Barros, L.; Ferreira, M.-J.; Queirós, B.; Ferreira, I.; Baptista, P. Total phenols, ascorbic acid, $\beta$-carotene and lycopene in Portuguese wild edible mushrooms and their antioxidant activities. Food Chem. 2007, 103, 413-419. [CrossRef]

136. Barros, L.; Baptista, P.; Ferreira, I.C. Effect of Lactarius piperatus fruiting body maturity stage on antioxidant activity measured by several biochemical assays. Food Chem. Toxicol. 2007, 45, 1731-1737. [CrossRef] [PubMed]

137. Dore, C.M.P.G.; Azevedo, T.C.G.; de Souza, M.C.R.; Rego, L.A.; de Dantas, J.C.M.; Silva, F.R.F.; Rocha, H.A.O.; Basela, I.G.; Leite, E.L. Antiinflammatory, antioxidant and cytotoxic actions of beta-glucan-rich extract from Geastrum saecatum mushroom. Int. Immunopharmacol. 2007, 7, 1160-1169. [CrossRef] [PubMed]

138. Kitzberger, C.S.G.; Smânia, A.; Pedrosa, R.C.; Ferreira, S.R.S. Antioxidant and antimicrobial activities of shiitake (Lentinula edodes) extracts obtained by organic solvents and supercritical fluids. J. Food Eng. 2007, 80, 631-638. [CrossRef]

139. Ng, L.T.; Wu, S.J.; Tsai, J.Y.; Lai, M.N. Antioxidant activities of cultured Armillariella mellea. Appl. Biochem. Microbiol. 2007, 43, 495-500. [CrossRef]

140. Oliveira, O.; Vellosa, J.C.R.; Fernandes, A.; Buffa-Filho, W.; Hakime-Silva, R.; Furlan, M.; Brunetti, I.L. Antioxidant activity of Agaricus blazei. Fitoterapia 2007, 78, 263-264. [CrossRef]

141. Barros, L.; Falcão, S.I.; Baptista, P.; Freire, C.; Vilas-Boas, M.; Ferreira, I.C. Antioxidant activity of Agaricus sp. mushrooms by chemical, biochemical and electrochemical assays. Food Chem. 2008, 111, 61-66. [CrossRef]

142. Soares, A.A.; De Souza, C.G.M.; Daniel, F.M.; Ferrari, G.P.; Da Costa, S.M.G.; Peralta, R.M. Antioxidant activity and total phenolic content of Agaricus brasiliensis (Agaricus blazei Murril) in two stages of maturity. Food Chem. 2009, 112, 775-781. [CrossRef]

143. Obodai, M.; Ferreira, I.C.; Fernandes, A.; Barros, L.; Mensah, D.L.N.; Dzomeku, M.; Urben, A.F.; Prempeh, J.; Takli, R.K. Evaluation of the chemical and antioxidant properties of wild and cultivated mushrooms of ghana. Molecules 2014, 19, 19532-19548. [CrossRef] [PubMed]

144. Jaszek, M.; Osińska-Jaroszuk, M.; Janusz, G.; Matuszewska, A.; Stefaniuk, D.; Sulej, J.; Polak, J.; Ruminowicz, M.; Grzywnowicz, K.; Jarosz-Wilkolazka, A. New bioactive fungal molecules with high antioxidant and antimicrobial capacity isolated from Cerrena unicolor idiophasic cultures. BioMed Res. Int. 2013, 2013, 497492. [CrossRef] [PubMed]

145. Weigand-Heller, J.; Kris-Etherton, P.M.; Beelman, R.B. The bioavailability of ergothioneine from mushrooms (Agaricus bisporus) and the acute effects on antioxidant capacity and biomarkers of inflammation. Prev. Med. 2012, 54, S75-S78. [CrossRef] [PubMed]

146. Encarnacion, A.B.; Fagutao, F.; Jintasataporn, O.; Worawattanamateekul, W.; Hirono, I.; Ohshima, T. Application of ergothioneinerich extract from an edible mushroom Flammulina velutipes for melanosis prevention in shrimp, Penaeus monodon and Litopenaeus vannamei. Food Res. Int. 2012, 45, 232-237. [CrossRef]

147. Encarnacion, A.B.; Fagutao, F.; Hirono, I.; Ushio, H.; Ohshima, T. Effects of ergothioneine from mushrooms (Flammulina velutipes) on melanosis and lipid oxidation of kuruma shrimp (Marsupenaeus japonicus). J. Agric. Food Chem. 2010, 58, 2577-2585. [CrossRef]

148. Bao, H.N.D.; Ushio, H.; Ohshima, T. Antioxidative Activity and antidiscoloration efficacy of ergothioneine in mushroom (Flammulina velutipes) extract added to beef and fish meats. J. Agric. Food Chem. 2008, 56, 10032-10040. [CrossRef]

149. Barros, L.; Dueñas, M.; Ferreira, I.C.; Baptista, P.; Santos-Buelga, C. Phenolic acids determination by HPLC-DAD-ESI/MS in sixteen different Portuguese wild mushrooms species. Food Chem. Toxicol. 2008, 47, 1076-1079. [CrossRef] 
150. Vunduk, J.; Klaus, A.; Kozarski, M.; Petrovic, P.; Zizak, Z.; Niksic, M.; van Griensven, L.J.L.D. Did the "Iceman" know better? Screening of the medicinal properties of Piptoporus betulinus. Int. J. Med. Mushrooms 2015, 17, 1113-1125. [CrossRef]

151. Wei, S.; Helsper, J.P.F.G.; Van Griensven, L.J.L.D. Phenolic compounds present in medicinal mushroom extracts generate reactive oxygen species in human cells in vitro. Int. J. Med. Mushrooms 2008, 10, 1-13. [CrossRef]

152. Dubost, N.J.; Beelman, R.B.; Peterson, D.; Royse, D.J. Identification and quantification of ergothioneine in cultivated mushrooms by liquid chromatography-mass spectroscopy. Int. J. Med. Mushrooms 2006, 8, 215-222. [CrossRef]

153. Muszynska, B.; Sulkowska-Ziaja, K.; Ekiert, H. Phenolic acids in selected edible basidiomycota species: Armillaria mellea, Boletus badius, Boletus edulis, Cantharellus cibarius, Lactarius deliciosus and Pleurotus ostreatus. Acta Sci. Pol. Hortorum Cultus 2013, 12, 107-116.

154. Cheung, Y.-C.; Siu, K.-C.; Liu, Y.-S.; Wu, J.-Y. Molecular properties and antioxidant activities of polysaccharideprotein complexes from selected mushrooms by ultrasound-assisted extraction. Process. Biochem. 2012, 47, 892-895. [CrossRef]

155. Chen, Y.; Xie, M.-Y.; Nie, S.-P.; Li, C.; Wang, Y.-X. Purification, composition analysis and antioxidant activity of a polysaccharide from the fruiting bodies of Ganoderma atrum. Food Chem. 2008, 107, 231-241. [CrossRef]

156. Barros, L.; Venturini, B.A.; Baptista, P.; Estevinho, M.L.M.F.; Ferreira, I.C.F.R. Chemical composition and biological properties of portuguese wild mushrooms: A comprehensive study. J. Agric. Food Chem. 2008, 56, 3856-3862. [CrossRef]

157. Suabjakyong, P.; Saiki, P.; Van Griensven, L.J.L.D.; Higashi, K.; Nishimura, K.; Igarashi, K.; Toida, T. Polyphenol extract from phellinus igniarius protects against acrolein toxicity in vitro and provides protection in a mouse stroke model. PLoS ONE 2015, 10, e0122733. [CrossRef]

158. Liu, Y.; Sun, J.; Luo, Z.-Y.; Rao, S.-Q.; Su, Y.-J.; Xu, R.-R.; Yang, Y.-J. Chemical composition of five wild edible mushrooms collected from Southwest China and their antihyperglycemic and antioxidant activity. Food Chem. Toxicol. 2012, 50, 1238-1244. [CrossRef]

159. Bai, M.-S.; Wang, C.; Zong, S.-C.; Lei, M.; Gao, J.-M. Antioxidant polyketide phenolic metabolites from the edible mushroom Cortinarius purpurascens. Food Chem. 2013, 141, 3424-3427. [CrossRef]

160. Liu, K.; Wang, J.; Zhao, L.; Wang, Q. Anticancer, antioxidant and antibiotic activities of mushroom Ramaria flava. Food Chem. Toxicol. 2013, 58, 375-380. [CrossRef]

161. Liu, J.; Jia, L.; Kan, J.; Jin, C.-H. In vitro and in vivo antioxidant activity of ethanolic extract of white button mushroom (Agaricus bisporus). Food Chem. Toxicol. 2013, 51, 310-316. [CrossRef]

162. Barbosa, J.R.; dos Santos Freitas, M.M.; da Silva Martins, L.H.; de Carvalho, R.N. Polysaccharides of mushroom Pleurotus spp.: New extraction techniques, biological activities and development of new technologies. Carbohydr. Polym. 2020, 229, 115550. [CrossRef]

163. Barbosa, J.R.; Freitas, M.M.S.; Oliveira, L.C.; Martins, L.H.S.; Almada-Vilhena, A.O.; Oliveira, R.M.; Pieczarka, J.C.; Brasil, D.D.S.B.; Carvalho Junior, R.N. Obtaining extracts rich in antioxidant polysaccharides from the edible mushroom Pleurotus ostreatus using binary system with hot water and supercritical CO2. Food Chem. 2020, 330, 127173. [CrossRef]

164. Chaiyama, V.; Keawsompong, S.; LeBlanc, J.G.; De LeBlanc, A.D.M.; Chatel, J.M.; Chanput, W. Action modes of the immune modulating activities of crude mushroom polysaccharide from Phallus atrovolvatus. Bioact. Carbohydr. Diet. Fibre 2020, $23,100216$. [CrossRef]

165. Mingyi, Y.; Belwal, T.; Devkota, H.P.; Li, L.; Luo, Z. Trends of utilizing mushroom polysaccharides (MPs) as potent nutraceutical components in food and medicine: A comprehensive review. Trends Food Sci. Technol. 2019, 92, 94-110. [CrossRef]

166. Weis, A.L.; Wasser, S.P. Therapeutic effects of substances occurring in higher basidiomycetes mushrooms: A modern perspective. Crit. Rev. Immunol. 1999, 19, 32-96. [CrossRef]

167. Wasser, S.P. Medicinal mushroom science: History, current status, future trends, and unsolved problems. Int. J. Med. Mushrooms 2010, 12, 1-16. [CrossRef]

168. Batbayar, S.; Lee, D.-H.; Kim, H.-W. Immunomodulation of fungal $\beta$-Glucan in host defense signaling by dectin-1. Biomol. Ther. 2012, 20, 433-445. [CrossRef] [PubMed]

169. Cipriani, T.R.; Mellinger, C.G.; de Souza, L.M.; Baggio, C.H.; Freitas, C.S.; Marques, M.C.A.; Gorin, P.A.J.; Sassaki, G.L.; Iacomini, M. A polysaccharide from a tea (infusion) of Maytenus ilicifolia leaves with anti-ulcer protective effects. J. Nat. Prod. 2006, 69, 1018-1021. [CrossRef]

170. Bhattacharyya, A.; Chattopadhyay, R.; Mitra, S.; Crowe, S.E. Oxidative stress: An essential factor in the pathogenesis of gastrointestinal mucosal diseases. Physiol. Rev. 2014, 94, 329-354. [CrossRef]

171. Babior, B.M.; Woodman, R.C. Chronic granulomatous disease. Semin. Hematol. 1990, 27, 247-259. [PubMed]

172. Fang, F.C. Antimicrobial reactive oxygen and nitrogen species: Concepts and controversies. Nat. Rev. Microbiol. 2004, 2, 820-832. [CrossRef] [PubMed]

173. Wu, S.; Li, F.; Jia, S.; Ren, H.; Gong, G.; Wang, Y.; Lv, Z.; Liu, Y. Drying effects on the antioxidant properties of polysaccharides obtained from Agaricus blazei Murrill. Carbohydr. Polym. 2014, 103, 414-417. [CrossRef]

174. Mao, G.; Feng, W.; Xiao, H.; Zhao, T.; Li, F.; Zou, Y.; Ren, Y.; Zhu, Y.; Yang, L.; Wu, X. Purification, characterization, and antioxidant activities of selenium-containing proteins and polysaccharides in royalsun mushroom, Agaricus brasiliensis (higher Basidiomycetes). Int. J. Med. Mushrooms 2014, 16, 463-475. [CrossRef]

175. Salvador, C.; Martins, M.R.; Caldeira, A.T. Microanalysis characterization of bioactive protein-bound polysaccharides produced by Amanita ponderosa cultures. Microsc. Microanal. 2015, 21, 84-90. [CrossRef] 
176. Zhu, Z.Y.; Zhang, J.Y.; Chen, L.J.; Liu, X.C.; Liu, Y.; Wang, W.X.; Zhang, Y.M. Comparative evaluation of polysaccharides isolated from Astragalus, oyster mushroom, and yacon as inhibitors of $\alpha$-glucosidase. Chin. J. Nat. Med. 2014, 12, 290-293. [CrossRef]

177. Zhao, S.; Rong, C.; Liu, Y.; Xu, F.; Wang, S.; Duan, C.; Chen, J.; Wu, X. Extraction of a soluble polysaccharide from Auricularia polytricha and evaluation of its anti-hypercholesterolemic effect in rats. Carbohydr. Polym. 2015, 122, 39-45. [CrossRef]

178. Wang, D.; Sun, S.-Q.; Wu, W.-Z.; Yang, S.-L.; Tan, M.-J. Characterization of a water-soluble polysaccharide from Boletus edulis and its antitumor and immunomodulatory activities on renal cancer in mice. Carbohydr. Polym. 2014, 105, 127-134. [CrossRef] [PubMed]

179. Moreno, R.B.; Ruthes, A.C.; Baggio, C.H.; Vilaplana, F.; Komura, D.L.; Iacomini, M. Structure and antinociceptive effects of $\beta$-D-glucans from Cookeina tricholoma. Carbohydr. Polym. 2016, 141, 220-228. [CrossRef] [PubMed]

180. Jing, Y.; Zhu, J.; Liu, T.; Bi, S.; Hu, X.; Chen, Z.; Song, L.; Lv, W.; Yu, R. Structural characterization and biological activities of a novel polysaccharide from cultured Cordyceps militaris and its sulfated derivative. J. Agric. Food Chem. 2015, 63, 3464-3471. [CrossRef] [PubMed]

181. Zhang, Z.F.; Lv, G.Y.; Jiang, X.; Cheng, J.H.; Fan, L.F. Extraction optimization and biological properties of a polysaccharide isolated from Gleoestereum incarnatum. Carbohydr. Polym. 2015, 117, 185-191. [CrossRef] [PubMed]

182. Zhou, H.; Liu, G.; Huang, F.; Wu, X.; Yang, H. Improved production, purification and bioactivity of apolysaccharide from submerged cultured Ganoderma lucidum. Arch. Pharm. Res. 2014, 37, 1530-1537. [CrossRef]

183. Ma, X.; Zhou, F.; Chen, Y.; Zhang, Y.; Hou, L.; Cao, X.; Wang, C. A polysaccharide from Grifola frondosarelieves insulin resistance of HepG2 cell by Akt-GSK-3 pathway. Glycoconj. J. 2014, 31, 355-363. [CrossRef] [PubMed]

184. Mao, G.H.; Ren, Y.; Feng, W.W.; Li, Q.; Wu, H.Y.; Jin, D.; Zhao, T.; Xu, C.Q.; Yang, L.Q.; Wu, X.Y. Antitumorand immunomodulatory activity of a water-soluble polysaccharide from Grifola frondosa. Carbohydr. Polym. 2015, 134, 406-412. [CrossRef] [PubMed]

185. Li, X.; Wang, L. Effect of extraction method on structure and antioxidant activity of Hohenbuehelia serotinapolysaccharides. Int. J. Biol. Macromol. 2016, 83, 270-276. [CrossRef]

186. Yan, P.S.; Cao, L.X.; Zhang, B.Z. Efficient purification of antiproliferative polysaccharides from Hypsizigus marmoreus with radial flow chromatography. Biotechnol. Prog. 2014, 30, 872-878. [CrossRef] [PubMed]

187. Ren, L.; Edwards, P.J.; Perera, C.O.; Hemar, Y. Structural features of a novel polysaccharide isolated from a New Zealand Maori mushroom Iliodiction cibarium. Carbohydr. Res. 2015, 406, 19-26. [CrossRef]

188. Villares, A. Isolation and characterization of a glucan-type polysaccharide from the red pine mushroom, Lactarius deliciosus (higher Basidiomycetes). Int. J. Med. Mushrooms 2013, 15, 583-589. [CrossRef]

189. Wang, L.; Wang, C.; Gao, X.; Xu, N.; Lin, L.; Zhao, H.; Jia, S.; Jia, L. Purification, characterization andanti-aging capacity of mycelia zinc polysaccharide by Lentinus edodes SD-08. BMC Complement. Altern. Med. 2015, 15, 111. [CrossRef]

190. Samanta, S.; Nandi, A.K.; Sen, I.K.; Maity, P.; Pattanayak, M.; Devi, K.S.P.; Khatua, S.; Maiti, T.K.; Acharya, K.; Islam, S.S. Studies on antioxidative and immunostimulating fucogalactan of the edible mushroom Macrolepiota dolichaula. Carbohydr. Res. 2015, 413, 22-29. [CrossRef]

191. Cao, X.Y.; Liu, J.L.; Yang, W.; Hou, X.; Li, Q.J. Antitumor activity of polysaccharide extracted from Pleurotus ostreatus mycelia against gastric cancer in vitro and in vivo. Mol. Med. Rep. 2015, 12, 2383-2389. [CrossRef]

192. Zhao, C.; Liao, Z.; Wu, X.; Liu, Y.; Liu, X.; Lin, Z.; Huang, Y.; Liu, B. Isolation, purification, and structuralfeatures of a polysaccharide from Phellinus linteus and its hypoglycemic effect in alloxan-induced diabeticmice. J. Food Sci. 2014, 79, H1002-H1010. [CrossRef]

193. Yang, K.; Jin, Y.; Xing, C.; Hu, J.; Wang, R.; Sun, P. Chemical characterization and in vitro antioxidantactivity evaluation of polysaccharides from the fruiting bodies of the red heart mushroom Phellinus pini (higher Basidiomycetes). Int. J. Med. Mushrooms 2015, 17, 297-307. [CrossRef] [PubMed]

194. Hu, Q.; Wang, H.; Ng, T.B. Isolation and purification of polysaccharides with anti-tumor activity from Pholiota adiposa (Batsch) P. Kumm. (higher Basidiomycetes). Int. J. Med. Mushrooms 2012, 14, 271-284. [CrossRef] [PubMed]

195. Zhang, J.; Xu, N.; Wang, G.; Zhao, H.; Lin, L.; Jia, M.; Jia, L. In vitro and in vivo antioxidant effects of polysaccharides from Nameko medicinal mushroom, Pholiota nameko SW-01 (higher Basidiomycetes). Int. J. Med. Mushrooms 2015, 17, 671-680. [CrossRef] [PubMed]

196. Ma, G.; Yang, W.; Mariga, A.M.; Fang, Y.; Ma, N.; Pei, F.; Hu, Q. Purification, characterization and antitumoractivity of polysaccharides from Pleurotus eryngii residue. Carbohydr. Polym. 2014, 114, 297-305. [CrossRef] [PubMed]

197. Zhang, Y.; Hu, T.; Zhou, H.; Zhang, Y.; Jin, G.; Yang, Y. Antidiabetic effect of polysaccharides from Pleurotus ostreatus in streptozotocin-induced diabetic rats. Int. J. Biol. Macromol. 2016, 83, 126-132. [CrossRef]

198. Manna, D.K.; Nandi, A.K.; Pattanayak, M.; Maity, P.; Tripathy, S.; Mandal, A.K.; Roy, S.; Tripathy, S.S.; Gupta, N.; Islam, S.S. A water soluble $\beta$-glucan of an edible mushroom Termitomyces heimii: Structural and biological investigation. Carbohydr. Polym. 2015, 134, 375-384. [CrossRef]

199. Cheng, H.; Jia, Y.; Wang, L.; Liu, X.; Liu, G.; Li, L.; He, C. Isolation and structural elucidation of a novel homogenous polysaccharide from Tricholoma matsutake. Nat. Prod. Res. 2016, 30, 58-64. [CrossRef]

200. You, Q.; Yin, X.; Zhao, Y.; Jiang, Z. Extraction and purification of polysaccharides from pine medicinal mushroom, Tricholoma matsutake (higher Basidiomycetes) fruit bodies. Int. J. Med. Mushrooms 2014, 16, 149-160. [CrossRef]

201. Yin, X.; You, Q.; Su, X. A comparison study on extraction of polysaccharides from Tricholoma matsutake by response surface methodology. Carbohydr. Polym. 2014, 102, 419-422. [CrossRef] 
202. Zhao, Y.M.; Song, J.H.; Wang, J.; Yang, J.M.; Wang, Z.B.; Liu, Y.H. Optimization of cellulase-assisted extraction process and antioxidant activities of polysaccharides from Tricholoma mongolicum Imai. J. Sci. Food Agric. 2016, 96, 4484-4491. [CrossRef]

203. Masuda, Y.; Nawa, D.; Nakayama, Y.; Konishi, M.; Nanba, H. Soluble $\beta$-glucan from Grifola frondosa induces tumor regression in synergy with TLR9 agonist via dendritic cell-mediated immunity. J. Leukoc. Biol. 2015, 98, 1015-1025. [CrossRef] [PubMed]

204. Pan, H.; Han, Y.; Huang, J.; Yu, X.; Jiao, C.; Yang, X.; Dhaliwal, P.; Xie, Y.; Yang, B.B. Purification and identification of a polysaccharide from medicinal mushroom Amauroderma rude with immunomodulatory activity and inhibitory effect on tumor growth. Oncotarget 2015, 6, 17777-17791. [CrossRef]

205. Chang, J.S.; Kuo, H.P.; Chang, K.L.; Kong, Z.L. Apoptosis of hepatocellular carcinoma cells induced by nanoencapsulated polysaccharides extracted from Antrodia camphorata. PLoS ONE 2015, 10, e0136782. [CrossRef] [PubMed]

206. Kim, S.P.; Nam, S.H.; Friedman, M. Correction to Hericium erinaceus (Lion's Mane) Mushroom Extracts Inhibit Metastasis of Cancer Cells to the Lung in CT-26 Colon Cancer-Transplanted Mice. J. Agric. Food Chem. 2013, 61, 5411. [CrossRef]

207. Gaullier, J.M.; Sleboda, J.; Øfjord, E.S.; Ulvestad, E.; Nurminiemi, M.; Moe, C.; Tor, A.; Gudmundsen, O. Supplementation with a soluble-glucan exported from Shiitake medicinal mushroom, Lentinus edodes (Berk.) singer mycelium: A crossover, placebo-controlled study in healthy elderly. Int. J. Med. Mushrooms 2011, 13, 319-326. [CrossRef] [PubMed]

208. Meng, X.; Liang, H.; Luo, L. Antitumor polysaccharides from mushrooms: A review on the structural characteristics, antitumor mechanisms and immunomodulating activities. Carbohydr. Res. 2016, 424, 30-41. [CrossRef]

209. Yan, J.K.; Pei, J.J.; Ma, H.L.; Wang, Z.B.; Liu, Y.S. Advances in antitumor polysaccharides from Phellinus sensu lato: Production, isolation, structure, antitumor activity, and mechanisms. Crit. Rev. Food Sci. Nutr. 2015, 57, 1256-1269. [CrossRef]

210. Bergendiova, K.; Tibenska, E.; Majtan, J. Pleuran ( $\beta$-glucan from Pleurotus ostreatus) supplementation, cellular immune response and respiratory tract infections in athletes. Eur. J. Appl. Physiol. 2011, 111, 2033-2040. [CrossRef]

211. Sen, I.K.; Mandal, A.K.; Chakraborti, S.; Dey, B.; Chakraborty, R.; Islam, S.S. Green synthesis of silver nanoparticles using glucan from mushroom and study of antibacterial activity. Int. J. Biol. Macromol. 2013, 62, 439-449. [CrossRef]

212. Cui, H.-Y.; Wang, C.-L.; Wang, Y.-R.; Li, Z.-J.; Chen, M.-H.; Li, F.-J.; Sun, Y.-P. Pleurotus nebrodensis polysaccharide (PN-S) enhances the immunity of immunosuppressed mice. Chin. J. Nat. Med. 2015, 13, 760-766. [CrossRef]

213. Hu, S.-H.; Cheung, P.C.K.; Hung, R.-P.; Chen, Y.-K.; Wang, J.-C.; Chang, S.-J. Antitumor and immunomodulating activities of exopolysaccharide produced by big cup culinary-medicinal mushroom Clitocybe maxima (higher Basidiomycetes) in liquid submerged culture. Int. J. Med. Mushrooms 2015, 17, 891-901. [CrossRef]

214. Kim, S.P.; Park, S.O.; Lee, S.J.; Nam, S.H.; Friedman, M. A polysaccharide isolated from the liquid culture of Lentinus edodes (Shiitake) mushroom mycelia containing black rice bran protects mice against a Salmonella lipopolysaccharide-induced endotoxemia. J. Agric. Food Chem. 2013, 61, 10987-10994. [CrossRef]

215. Kim, S.P.; Moon, E.; Nam, S.H.; Friedman, M. Hericium erinaceus mushroom extracts protect infected mice against Salmonella Typhimurium-induced liver damage and mortality by stimulation of innate immune cells. J. Agric. Food Chem. 2012, 60, 5590-5596. [CrossRef] [PubMed]

216. Signoretto, C.; Marchi, A.; Bertoncelli, A.; Burlacchini, G.; Papetti, A.; Pruzzo, C.; Zaura, E.; Lingström, P.; Ofek, I.; Pratten, J.; et al. The anti-adhesive mode of action of a purified mushroom (Lentinus edodes) extract with anticaries and antigingivitis properties in two oral bacterial phatogens. BMC Complement. Altern. Med. 2014, 14, 75. [CrossRef] [PubMed]

217. Cai, M.; Lin, Y.; Luo, Y.L.; Liang, H.H.; Sun, P.L. Extraction, antimicrobial, and antioxidant activities of crude polysaccharides from the Wood Ear medicinal mushroom Auricularia auricula-judae (higher Basidiomycetes). Int. J. Med. Mushrooms 2015, 17, 591-600. [CrossRef] [PubMed]

218. Li, S.; Shah, N.P. Antioxidant and antibacterial activities of sulphated polysaccharides from Pleurotus eryngii and Streptococcus thermophilus ASCC 1275. Food Chem. 2014, 165, 262-270. [CrossRef]

219. Friedman, M. Chemistry, Nutrition, and health-promoting properties of Hericium erinaceus (Lion's Mane) mushroom fruiting bodies and mycelia and their bioactive compounds. J. Agric. Food Chem. 2015, 63, 7108-7123. [CrossRef]

220. Chen, P.; Yong, Y.; Gu, Y.; Wang, Z.; Zhang, S.; Lu, L. Comparison of antioxidant and antiproliferation activities of polysaccharides from eight species of medicinal mushrooms. Int. J. Med. Mushrooms 2015, 17, 287-295. [CrossRef]

221. Zhu, Y.; Chen, Y.; Li, Q.; Zhao, T.; Zhang, M.; Feng, W.; Takase, M.; Wu, X.; Zhou, Z.; Yang, L.; et al. Preparation, characterization, and anti-Helicobacter pylori activity of Bi3+-Hericium erinaceus polysaccharide complex. Carbohydr. Polym. 2014, 110, 231-237. [CrossRef]

222. Huang, H.Y.; Korivi, M.; Chaing, Y.Y.; Chien, T.Y.; Tsai, Y.C. Pleurotus tuber-regium polysaccharides attenuate hyper-glycemia and oxidative stress in experimental diabetic rats. Evid. Based Complement. Altern. Med. 2012, 2012, 856381. [CrossRef]

223. Huang, H.Y.; Korivi, M.; Yang, H.T.; Huang, C.C.; Chaing, Y.Y.; Tsai, Y.C. Effect of Pleurotus tuber-regium polysaccha-rides supplementation on the progression of diabetes complications in obese-diabetic rats. Chin. J. Physiol. 2014, 57, 198-208. [CrossRef]

224. Berven, L.; Karppinen, P.; Hetland, G.; Samuelsen, A.B.C. The polar high molecular weight fraction of the Agaricus blazei Murill extract, AndoSan, reduces the activity of the tumor-associated protease, legumain, in RAW 264.7 cells. J. Med. Food 2015, 18, 429-438. [CrossRef] [PubMed]

225. Hetland, G.; Johnson, E.; Lyberg, T.; Kvalheim, G. The mushroom Agaricus blazei Murill elicits medicinal effects on tumor, infection, allergy, and inflammation through Its modulation of innate immunity and amelioration of Th1/Th2 imbalance and inflammation. Adv. Pharmacol. Sci. 2011, 2011, 157015. [PubMed] 
226. Tangen, J.-M.; Tierens, A.; Caers, J.; Binsfeld, M.; Olstad, O.K.; Trøseid, A.-M.S.; Wang, J.; Tjønnfjord, G.E.; Hetland, G. Immunomodulatory effects of the Agaricus blazei Murrill-based mushroom extract AndoSan in patients with multiple myeloma undergoing high dose chemotherapy and autologous stem cell transplantation: A randomized, double blinded clinical study. BioMed Res. Int. 2015, 2015, 718539. [CrossRef] [PubMed]

227. Chen, L.; Shao, H. Extract from Agaricus blazei Murill can enhance immune responses elicited by DNA vaccine against foot-and-mouth disease. Vet. Immunol. Immunopathol. 2006, 109, 177-182. [CrossRef]

228. Kim, H.G.; Shrestha, B.; Lim, S.Y.; Yoon, D.H.; Chang, W.C.; Shin, D.-J.; Han, S.K.; Park, J.H.; Park, H.; Sung, J.-M.; et al. Cordycepin inhibits lipopolysaccharide-induced inflammation by the suppression of NF- $\mathrm{B}$ through Akt and p38 inhibition in RAW 264.7 macrophage cells. Eur. J. Pharmacol. 2006, 545, 192-199. [CrossRef]

229. Yang, X.; Li, Y.; He, Y.; Li, T.; Wang, W.; Zhang, J.; Wei, J.; Deng, Y.; Lin, R. Cordycepin alleviates airway hyperreactivity in a murine model of asthma by attenuating the inflammatory process. Int. Immunopharmacol. 2015, 26, 401-408. [CrossRef]

230. Mueller, W.E.G.; Weiler, B.E.; Charubala, R.; Pfleiderer, W.; Leserman, L.; Sobol, R.W.; Suhadolnik, R.J.; Schroeder, H.C. Cordycepin analogs of $2^{\prime}, 5^{\prime}$-oligoadenylate inhibit human immunodeficiency virus infection via inhibition of reverse transcriptase. Biochemistry 1991, 30, 2027-2033. [CrossRef]

231. Jiang, Y.; Wong, J.H.; Fu, M.; Ng, T.B.; Liu, Z.K.; Wang, C.R.; Li, N.; Qiao, W.T.; Wen, T.Y.; Liu, F. Isolation of adenosine, iso-sinensetin and dimethylguanosine with antioxidant and HIV-1 protease inhibiting activities from fruiting bodies of Cordyceps militaris. Phytomedicine 2011, 18, 189-193. [CrossRef]

232. Lee, H.H.; Park, H.; Sung, G.-H.; Lee, K.; Lee, T.; Lee, I.; Park, M.-S.; Jung, Y.W.; Shin, Y.S.; Kang, H.; et al. Anti-influenza effect of Cordyceps militaris through immunomodulation in a DBA/2 mouse model. J. Microbiol. 2014, 52, 696-701. [CrossRef]

233. Ohta, Y.; Lee, J.-B.; Hayashi, K.; Fujita, A.; Park, D.K.; Hayashi, T. In vivo anti-influenza virus activity of an immunomodulato-ry acidic polysaccharide isolated from Cordyceps militaris grown on germinated soybeans. J. Agric. Food Chem. 2007, 55, 10194-10199. [CrossRef]

234. Badalyan, S.M. Edible and medicinal higher basidiomycetes mushrooms as a source of natural antioxidants. Int. J. Med. Mushrooms 2003, 5, 153-162. [CrossRef]

235. Mau, J.-L.; Lin, H.-C.; Chen, C.-C. Antioxidant properties of several medicinal mushrooms. J. Agric. Food Chem. 2002, 50, 6072-6077. [CrossRef] [PubMed]

236. Kim, M.-Y.; Seguin, P.; Ahn, J.-K.; Kim, J.-J.; Chun, S.-C.; Kim, E.-H.; Seo, S.-H.; Kang, E.-Y.; Kim, S.-L.; Park, Y.-J.; et al. Phenolic compound concentration and antioxidant activities of edible and medicinal mushrooms from Korea. J. Agric. Food Chem. 2008, 56, 7265-7270. [CrossRef] [PubMed]

237. Sulkowska-Ziaja, K.; Muszynska, B.; Motyl, P.; Pasko, P.; Ekiert, H. Phenolic compounds and antioxidant activity in some species of polyporoid mushrooms from Poland. Int. J. Med. Mushrooms 2012, 14, 385-393. [CrossRef]

238. Aziz, T.; Mehmet, E.D.; Nazime, M.; Ibrahim, K.; Kudret, G. Antimicrobial and antioxidant activities of mycelia of 10 wild mushroom species. J. Med. Food 2010, 13, 415-419.

239. Lee, I.-K.; Kim, Y.-S.; Jang, Y.-W.; Jung, J.-Y.; Yun, B.-S. New antioxidant polyphenols from the medicinal mushroom Inonotus obliquus. Bioorg. Med. Chem. Lett. 2007, 17, 6678-6681. [CrossRef]

240. Song, X.; Cai, W.; Ren, Z.; Jia, L.; Zhang, J. Antioxidant and hepatoprotective effects of acidic-hydrolysis residue polysaccharides from shiitake culinary-medicinal mushroom Lentinus edodes (Agaricomycetes) in mice. Int. J. Med. Mushrooms 2021, $23,85-96$. [CrossRef]

241. Ebrahimzadeh, M.A.; Nabavi, S.M.; Nabavi, S.F.; Eslami, S. Antioxidant and free radical scavenging activities of culinarymedicinal mushrooms, golden chanterelle Cantharellus cibarius and angel's wings Pleurotus porrigens. Int. J. Med. Mushrooms 2010, 12, 265-272. [CrossRef]

242. Woldegiorgis, A.Z.; Abate, D.; Haki, G.D.; Ziegler, G. Antioxidant property of edible mushrooms collected from Ethiopia. Food Chem. 2014, 157, 30-36. [CrossRef]

243. Liang, C.-H.; Ho, K.-J.; Huang, L.-Y.; Tsai, C.-H.; Lin, S.-Y.; Mau, J.-L. Antioxidant properties of fruiting bodies, mycelia, and fermented products of the culinary-medicinal king oyster mushroom, Pleurotus eryngii (higher Basidiomycetes), with high ergothioneine content. Int. J. Med. Mushrooms 2013, 15, 267-275. [CrossRef]

244. Nhi, N.; Hung, P. Nutritional composition and antioxidant capacity of several edible mushrooms grown in the Southern Vietnam. Int. Food Res. J. 2012, 19, 611-615.

245. Mau, J.-L.; Tsai, S.-Y.; Tseng, Y.-H.; Huang, S.-J. Antioxidant properties of hot water extracts from Ganoderma tsugae Murrill. LWT 2005, 38, 589-597. [CrossRef]

246. Barros, L.; Baptista, P.; Estevinho, L.; Ferreira, I.; Estevinho, M.L.M.F. Bioactive properties of the medicinal mushroom Leucopaxillus giganteus mycelium obtained in the presence of different nitrogen sources. Food Chem. 2007, 105, 179-186. [CrossRef]

247. Tsai, S.-Y.; Huang, S.-J.; Lo, S.-H.; Wu, T.-P.; Lian, P.-Y.; Mau, J.-L. Flavour components and antioxidant properties of several cultivated mushrooms. Food Chem. 2009, 113, 578-584. [CrossRef]

248. Wong, J.Y.; Chye, F.Y. Antioxidant properties of selected tropical wild edible mushrooms. J. Food Compos. Anal. 2009, 22, 269-277. [CrossRef]

249. Kalač, P. (Ed.) Edible Mushrooms: Chemical Composition and Nutritional Value; Elsevier Academic Press: Cambridge, CA, USA, 2016. 
250. Masterson, C.H.; Murphy, E.J.; Gonzalez, H.; Major, I.; Mccarthy, S.D.; O’Toole, D.; Rowan, N.J. Purified $\beta$-glucans from the Shiitake mushroomameliorates antibiotic-resistant Klebsiella pneumoniae-induced pulmonary sepsis. Lett. Appl. Microbiol. 2020, 71, 405-412. [PubMed]

251. Lee, J.S.; Hong, E.K. Immunostimulating activity of the polysaccharides isolated from Cordyceps militaris. Int. Immunopharmacol. 2011, 11, 1226-1233. [CrossRef]

252. Zhu, L.; Tang, Q.; Zhou, S.; Liu, Y.; Zhang, Z.; Gao, X.; Wang, S.; Wang, Z. Isolation and purification of apolysaccharide from the caterpillar medicinal mushroom Cordyceps militaris (Ascomycetes) fruit bodies and its immunomodulation of RAW 264.7 macrophages. Int. J. Med. Mushrooms 2014, 16, 247-257. [CrossRef]

253. Mu, H.; Zhang, A.; Zhang, W.; Cui, G.; Wang, S.; Duan, J. Antioxidative properties of crude polysaccharides from Inonotus obliquus. Int. J. Mol. Sci. 2012, 13, 9194-9206. [CrossRef]

254. Zhang, Z.; Lv, G.; Pan, H.; Pandey, A.; He, W.; Fan, L. Antioxidant and hepatoprotective potential of endo-polysaccharides from Hericium erinaceus grown on tofu whey. Int. J. Biol. Macromol. 2012, 51, 1140-1146. [CrossRef]

255. Nandi, A.K.; Samanta, S.; Maity, S.; Sen, I.K.; Khatua, S.; Devi, K.S.P.; Acharya, K.; Maiti, T.K.; Islam, S.S. Antioxidant and immunostimulant $\beta$-glucan from edible mushroom Russula albonigra (Krombh.) Fr. Carbohydr. Polym. 2014, 99, 774-782. [CrossRef]

256. Cheng, J.H.; Tsai, C.L.; Lien, Y.Y.; Lee, M.S.; Sheu, S.C. High molecular weight of polysaccharides from Hericium erinaceus against amyloid $\beta$-induced neurotoxicity. BMC Complement. Altern. Med. 2016, 16, 170. [CrossRef]

257. Fang, L.; Zhang, Y.; Xie, J.; Wang, L.; Zhang, H.; Wei, W.; Li, Y. Royal Sun medicinal mushroom, Agaricus brasiliensis (Agaricomycetidae), derived polysaccharides rxert immunomodulatory activities in vitro and in vivo. Int. J. Med. Mushrooms 2016, 18, 123-132. [CrossRef] [PubMed]

258. Yin, X.; You, Q.; Zhou, X. Complex enzyme-assisted extraction, purification, and antioxidant activity of polysaccharides from the button mushroom, Agaricus bisporus (higher Basidiomycetes). Int. J. Med. Mushrooms 2015, 17, 987-996. [CrossRef] [PubMed]

259. Alzorqi, I.; Sudheer, S.; Lu, T.J.; Manickam, S. Ultrasonically extracted $\beta$-D-glucan from artificially cultivated mushroom, characteristic properties and antioxidant activity. Ultrason. Sonochem. 2016, 35, 531-540. [CrossRef]

260. Maity, P.; Sen, I.K.; Maji, P.K.; Paloi, S.; Devi, K.S.P.; Acharya, K.; Maiti, T.K.; Islam, S.S. Structural, immunological, and antioxidant studies of $\beta$-glucan from edible mushroom Entoloma lividoalbum. Carbohydr. Polym. 2015, 123, 350-358. [CrossRef] [PubMed]

261. Lima, A.T.; Santos, M.N.; de Souza, L.A.; Pinheiro, T.S.; Paiva, A.A.; Dore, C.M.; Costa, M.S.; Santos, N.D.; Baseia, Y.G.; Araujo, R.M.; et al. Chemical characteristics of a heteropolysaccharide from Tylopilus ballouiimushroom and its antioxidant and anti-inflammatory activities. Carbohydr. Polym. 2016, 144, 400-409. [CrossRef] [PubMed]

262. Li, X.; Wang, Z.; Wang, L.; Walid, E.; Zhang, H. In vitro antioxidant and anti-proliferation activities of polysaccharides from various extracts of different mushrooms. Int. J. Mol. Sci. 2012, 13, 5801-5817. [CrossRef]

263. Khatua, S.; Paul, S.; Acharya, K. Mushroom as the potential source of new generation of antioxidant: A review. Res. J. Pharm. Technol. 2013, 6, 496-505.

264. Mohsin, M.; Negi, P.S.; Ahmed, Z. Determination of the antioxidant activity and polyphenol contents of wild Lingzhi or Reishi medicinal mushroom, Ganoderma lucidum (W. Curt. Fr.) P. Karst. (higher Basidiomycetes) from central Himalayan hills of India. Int. J. Med. Mushrooms 2011, 13, 535-544. [CrossRef]

265. Mathew, J.; Sudheesh, N.P.; Rony, K.A.; Smina, T.P.; Janardhanan, K.K. Antioxidant and antitumor activities of cultured mycelium of culinary-medicinal paddy straw mushroom Volvariella volvacea (Bull.: Fr.) singer (agaricomycetideae). Int. J. Med. Mushrooms 2008, 10, 139-147. [CrossRef]

266. Turkoglu, A.; Kivrak, I.; Mercan, N.; Duru, M.E.; Gezer, K.; Turkoglu, H. Antioxidant and antimicrobial activities of Morchella conica Pers. Afr. J. Biotechnol. 2006, 5, 1146-1150.

267. Mau, J.-L.; Tsai, S.-Y.; Tseng, Y.-H.; Huang, S.-J. Antioxidant properties of methanolic extracts from Ganoderma tsugae. Food Chem. 2005, 93, 641-649. [CrossRef]

268. Xiao, J.-H.; Xiao, D.-M.; Chen, D.-X.; Xiao, Y.; Liang, Z.-Q.; Zhong, J.-J. Polysaccharides from the medicinal mushroom cordyceps taii show antioxidant and immunoenhancing activities in a D-Galactose-induced aging mouse model. Evid. Based Complement. Altern. Med. 2012, 2012, 273435. [CrossRef] [PubMed]

269. Kozarski, M.; Klaus, A.; Niksic, M.; Van Griensven, L.J.L.D.; Vrvic, M.; Jakovljevic, D. Polysaccharides of higher fungi: Biological role, structure, and antioxidative activity. Chem. Ind. 2014, 68, 305-320. [CrossRef]

270. Lindequist, U.; Niedermeyer, T.; Jülich, W.-D. The pharmacological potential of mushrooms. Evid. Based Complement. Altern. Med. 2005, 2, 285-299. [CrossRef]

271. Tsiapali, E.; Whaley, S.; Kalbfleisch, J.; Ensley, H.E.; Browder, I.; Williams, D.L. Glucans exhibit weak antioxidant activity, but stimulate macrophage free radical activity. Free Radic. Biol. Med. 2001, 30, 393-402. [CrossRef]

272. Kishk, Y.F.M.; Al-Sayed, H.M.A. Free-radical scavenging and antioxidative activities of some polysaccharides in emulsions. LWT Food Sci. Technol. 2007, 40, 270-277. [CrossRef]

273. Brewer, M.S. Natural antioxidants: Sources, compounds, mechanisms of action, and potential applications. Compr. Rev. Food Sci. Food Saf. 2011, 10, 221-247. [CrossRef]

274. Ge, Q.; Mao, J.-W.; Zhang, A.-Q.; Wang, Y.-J.; Sun, P.-L. Purification, chemical characterization, and antioxidant activity of a polysaccharide from the fruiting bodies of sanghuang mushroom (Phellinus baumii Pilát). Food Sci. Biotechnol. 2013, 22, 301-307. [CrossRef] 
275. Li, N.; Li, L.; Fang, J.C.; Wong, J.H.; Ng, T.B.; Jiang, Y.; Wang, C.R.; Zhang, N.Y.; Wen, T.Y.; Qu, L.Y.; et al. Isolation and identification of a novel polysaccharide-peptide complex with antioxidant, anti-proliferative and hypoglycaemic activities from the abalone mushroom. Biosci. Rep. 2012, 32, 221-228. [CrossRef]

276. Tian, Y.T.; Zeng, H.L.; Xu, Z.B.; Zheng, B.D.; Lin, Y.X.; Gan, C.J.; Lo, Y.M. Ultrasonic-assisted extraction and antioxidant activity of polysaccharides recovered from white button mushroom (Agaricus bisporus). Carbohydr. Polym. 2012, 88, 522-529. [CrossRef]

277. Teplyakova, T.V.; Psurtseva, N.V.; Kosogova, T.A.; Mazurkova, N.A.; Khanin, V.A.; Vlasenko, V.A. Antiviral activity of polyporoid mushrooms (higher Basidiomycetes) from altai mountains (Russia). Int. J. Med. 2012, 14, 37-45. [CrossRef] [PubMed]

278. Ilyicheva, T.N.; Teplyakova, T.V.; Svyatchenko, S.V.; Asbaganov, S.V.; Zmitrovich, I.V.; Vlasenko, A.V. Antiviral activity of total polysaccharide fraction of water and ethanol extracts of pleurotus pulmonarius against the influenza a virus. Curr. Res. Environ. Appl. Mycol. J. Fungal Biol. 2020, 10, 224-235.

279. Zhang, M.; Cheung, P.C.; Ooi, V.E.; Zhang, L. Evaluation of sulfatedfungal $\beta$-glucans from the sclerotium of pleurotus tuberregium as a potential water-solubleanti-viral agent. Carbohydr. Res. 2004, 339, 2297-2301. [CrossRef] [PubMed]

280. Santoyo, S.; Ramírez-Anguiano, A.C.; Aldars-García, L.; Reglero, G.; Soler-Rivas, C. Antiviral activities of boletus edulis, Pleurotus ostreatus and lentinus edodes extracts and polysaccharide fractions against herpes simplex virus type 1. J. Food Nutr. Res. 2012, 51, 225-235.

281. Faccin, L.C.; Benati, F.; Rincao, V.P.; Mantovani, M.S.; Soares, S.A.; Gonzaga, M.L.; Carvalho Linhares, R.E. Antiviral activity of aqueous and ethanol extracts and of an isolated polysaccharide from agaricus brasiliensis against poliovirus type 1. Lett. Appl. Microbiol. 2007, 45, 24-28. [CrossRef]

282. Gu, C.-Q.; Li, J.-W.; Chao, F.; Jin, M.; Wang, X.-W.; Shen, Z.-Q. Isolation, identification and function of a novel anti-HSV-1 protein from Grifola frondosa. Antivir. Res. 2007, 75, 250-257. [CrossRef]

283. Zhao, C.; Gao, L.; Wang, C.; Liu, B.; Jin, Y.; Xing, Z. Structural characterization and antiviral activity of a novel heteropolysaccharide isolated from grifolafrondosa against enterovirus 71. Carbohydr. Polym. 2016, 144, 382-389. [CrossRef] [PubMed]

284. Shibnev, V.A.; Mishin, D.V.; Garaev, T.M.; Finogenova, N.P.; Botikov, A.G.; Deryabin, P.G. Antiviral activity of inonotus obliquus fungus extract towards infection caused by hepatitis c virus in cell cultures. Bull. Exp. Biol. Med. 2011, 151, 612-614. [CrossRef]

285. Roy, D.; Ansari, S.; Chatterjee, A.; Luganini, A.; Ghosh, S.K.; Chakraborty, N. In vitro search for antiviral activity against humancytomegalovirus from medicinal mushrooms Pleurotus sp. and Lentinus sp.. J. Antivir. Antiretrovir. 2020, $12,201$.

286. Stovall, M.; Smith, S.A.; Langholz, B.M.; Boice, J.D., Jr.; Shore, R.E.; Andersson, M.; Malone, K.E. Dose to the contralateral breast from radiotherapy and risk of second primary breast cancer in the WECARE study. Int. J. Radiat. Oncol. Biol. Phys. 2008, 72, 1021-1030. [CrossRef]

287. Elmekkawy, S.; Meselhy, M.R.; Nakamura, N.; Tezuka, Y.; Hattori, M.; Kakiuchi, N.; Shimotohno, K.; Kawahata, T.; Otake, T. Anti-HIV-1 and anti-HIV-1-protease substances from Ganoderma Lucidum. Phytochemistry 1998, 49, 1651-1657. [CrossRef]

288. Min, B.S.; Nakamura, N.; Miyashiro, H.; Bae, K.W.; Hattori, M. Triterpenes from the spores of Ganodermalucidum and their inhibitory activity against HIV-1 protease. Chem. Pharm. Bull. 1998, 46, 1607-1612. [CrossRef] [PubMed]

289. Martinez-Montemayor, M.; Ling, T.; Suárez-Arroyo, I.J.; Ortiz-Soto, G.; Santiago-Negrón, C.L.; Lacourt-Ventura, M.Y.; ValentínAcevedo, A.; Lang, W.H.; Rivas, F. Identification of biologically Active Ganoderma lucidum compounds and synthesis of improved derivatives That confer anti-cancer activities in vitro. Front. Pharmacol. 2019, 10, 115. [CrossRef] [PubMed]

290. El Dine, R.S.; Halawany, A.M.E.; Ma, C.M.; Hattori, M. Anti-HIV1- protease activity of lanostane triterpenes from the Vienamese mushroom Ganoderma colossum. J. Nat. Prod. 2008, 71, 1022-1026. [CrossRef] [PubMed]

291. El Dine, R.S.; El-Halawany, A.; Ma, C.-M.; Hattori, M. Inhibition of the dimerization and active site of HIV-1 protease by secondary metabolites from the vietnamese mushroom ganoderma colossum. J. Nat. Prod. 2009, 72, 2019-2023. [CrossRef]

292. Sillapachaiyaporn, C.; Nilkhet, S.; Ung, A.T.; Chuchawankul, S. Anti-HIV-1 protease activity of the crudeextracts and isolated compounds from Auricularia polytricha. BMC Complement. Altern. Med. 2019, 19, 351. [CrossRef]

293. Wang, J.; Wang, H.; Ng, T. A peptide with HIV-1 reverse transcriptase inhibitory activity from the medicinal mushroom Russula paludosa. Peptides 2007, 28, 560-565. [CrossRef]

294. Ueda, Y.; Mori, K.; Satoh, S.; Dansako, H.; Ikeda, M.; Kato, N. Anti-HCV activity of the Chinese medicinal fungus Cordyceps militaris. Biochem. Biophys. Res. Commun. 2014, 447, 341-345. [CrossRef] [PubMed]

295. Qian, G.-M.; Pan, G.-F.; Guo, J.-Y. Anti-inflammatory and antinociceptive effects of cordymin, a peptide purified from the medicinal mushroom Cordyceps sinensis. Nat. Prod. Res. 2012, 26, 2358-2362. [CrossRef] [PubMed]

296. Hsu, C.-H.; Sun, H.-L.; Sheu, J.-N.; Ku, M.-S.; Hu, C.-M.; Chan, Y.; Lue, K.H. Effects of the immunomodulatory agent Cordyceps militaris on airway inflammation in a mouse asthma model. Pediatr. Neonatol. 2008, 49, 171-178. [CrossRef]

297. Kelly, E.A.; Jarjour, N.N. Role of matrix metalloproteinases in asthma. Curr. Opin. Pulm. Med. 2003, 9, 28-33. [CrossRef] [PubMed]

298. Liu, Y.-K.; Shen, W. Inhibitive effect of cordyceps sinensis on experimental hepatic fibrosis and its possible mechanism. World J. Gastroenterol. 2003, 9, 529-533. [CrossRef] [PubMed]

299. Kaymakci, M.A.; Guler, E.M. Promising potential pharmaceuticals from the genus cordyceps for COVID-19 treatment: A review study. Bezmialem Sci. 2020, 8, 140-144. [CrossRef]

300. He, Y.; Li, X.; Hao, C.; Zeng, P.; Zhang, M.; Liu, Y.; Chang, Y.; Zhang, L. Grifola frondosa polysaccharide: A review of antitumor and other biological activity studies in China. Discov. Med. 2018, 25, 159-176.

301. Gu, C.-Q.; Li, J.W.; Chao, F.-H. Inhibition of hepatitis B virus by D-fraction from Grifola frondosa: Synergistic effect of combination with interferon- $\alpha$ in HepG2 2.2. Antivir. Res. 2006, 72, 162-165. [CrossRef] 
302. Nanba, H.; Kodama, N.; Schar, D.; Turner, D. Effects of maitake (Grifola frondosa) glucan in HIV-infected patients. Mycoscience 2000, 41, 293-295. [CrossRef]

303. Baraf, H.S. Efficacy of the newest COX-2 selective inhibitors in rheumatic disease. Curr. Pharm. Des. 2007, 13, 2228-2236. [CrossRef]

304. Bustillos, R.G.; Dulay, R.M.R.; Bauto, J.J.; Pascual, F.; Baltazar, K.; Bunag, H.W.; Macatula, A.; Nicolas, M.A.; Torres, M.A.A.; Nillosa, J.C.; et al. Mycochemical profle of mycelia and fruiting body of Panaeolus cyanescens and its optimal submerged culture conditions for antioxidant properties. Int. J. Pure Appl. Biosci. 2014, 2, 175-181.

305. Dhanasekaran, D.; Latha, S.; Suganya, P.; Panneerselvam, A.; Kumar, T.S.; Alharbi, N.S.; Arunachalam, C.; Alharbi, S.A.; Thajuddin, N. Taxonomic identification and bioactive compounds characterization of Psilocybe cubensis DPT1 to probe its antibacterial and mosquito larvicidal competency. Microb. Pathog. 2020, 143, 104138. [CrossRef] [PubMed]

306. Nkadimeng, S.M.; Nabatanzi, A.; Steinmann, C.M.; Eloff, J.N. Phytochemical, cytotoxicity, antioxidant and anti-inflammatory effects of Psilocybe Natalensis magic mushroom. Plants 2020, 9, 1127. [CrossRef] [PubMed]

307. Nkadimeng, S.M.; Steinmann, C.M.L.; Eloff, J.N. Effects and safety of Psilocybe cubensis and Panaeolus cyanescens magic mushroom extracts on endothelin-1-induced hypertrophy and cell injury in cardiomyocytes. Sci. Rep. 2020, 10, 22314. [CrossRef]

308. Elhusseiny, S.; El-Mahdy, T.; Awad, M.; Elleboudy, N.; Farag, M.; Aboshanab, K.; Yassien, M. Antiviral, cytotoxic, and antioxidant activities of three edible agaricomycetes mushrooms: Pleurotus columbinus, Pleurotus sajor-caju, and Agaricus bisporus. J. Fungi 2021, 7, 645. [CrossRef]

309. Singh, N.K.; Rao, G.N. Emerging role of 12/15-Lipoxygenase (ALOX15) in human pathologies. Prog. Lipid Res. 2019, 73, 28-45. [CrossRef]

310. Huang, C.; Wang, Y.; Li, X.; Ren, L.; Zhao, J.; Hu, Y.; Zhang, L.; Fan, G.; Xu, J.; Gu, X.; et al. Clinical features of patients infected with 2019 novel coronavirus in Wuhan, China. Lancet 2020, 395, 497-506. [CrossRef]

311. Stebbing, J.; Phelan, A.; Griffin, I.; Tucker, C.; Oechsle, O.; Smith, D.; Richardson, P. COVID-19: Combining antiviral and anti-inflammatory treatments. Lancet Infect. Dis. 2020, 20, 400-402. [CrossRef]

312. Lin, L.-T.; Hsu, W.-C.; Lin, C.-C. Antiviral natural products and herbal medicines. J. Tradit. Complement. Med. 2014, 4, 24-35. [CrossRef]

313. Shahzad, F.; Anderson, D.; Najafzadeh, M. The antiviral, anti-inflammatory effects of natural medicinal herbs and mushrooms and SARS-CoV-2 infection. Nutrients 2020, 12, 2573. [CrossRef]

314. Vilček, J.; Le, J. Interferon $\gamma$. In Encyclopedia of Immunology, 2nd ed.; Delves, P.J., Ed.; Elsevier: Oxford, UK, 1998.

315. Ren, G.; Xu, L.; Lu, T.; Yin, J. Structural characterization and antiviral activity of lentinan from Lentinus edodes mycelia against infectious hematopoietic necrosis virus. Int. J. Biol. Macromol. 2018, 115, 1202-1210. [CrossRef] [PubMed]

316. Abu-serie, M.M.; Habashy, N.H.; Attia, W.E. In vitro evaluation of the synergistic antioxidant andanti-inflammatory activities of the combined extracts from Malaysian Ganoderma lucidum and Egyptian Chlorella vulgaris. BMC Complement. Altern. Med. 2018, 18, 154. [CrossRef] [PubMed]

317. Hyun, K.; Jeong, S.; Lee, D.; Park, J.; Lee, J. Isolation and characterization of a novel platelet aggregation inhibitory peptide from the medicinal mushroom, Inonotus obliquus. Peptides 2006, 27, 1173-1178. [CrossRef] [PubMed]

318. Pan, H.-H.; Yu, X.-T.; Li, T.; Wu, H.-L.; Jiao, C.-W.; Cai, M.-H.; Li, X.-M.; Xie, Y.-Z.; Wang, Y.; Peng, T. Aqueous extract from a chaga medicinal mushroom, Inonotus obliquus (higher Basidiomyetes), prevents HerpesSimplex virus entry through inhibition of viral-induced membrane fusion. Int. J. Med. Mushrooms 2013, 15, 29-38. [CrossRef]

319. Lemieszek, M.; Langner, E.; Kaczor, J.; Kandefer-Szersze'n, M.; Sanecka, B.; Mazurkiewicz, W.; Rzeski, W. Anticancer effects of fraction isolated from fruiting bodies of chaga medicinal mushroom, Inonotus obliquus (Pers.: Fr.) Pilát (Aphyllophoromycetideae): In vitro studies. Int. J. Med. Mushrooms 2011, 13, 131-143. [CrossRef]

320. Filippova, E.I.; Mazurkova, N.A.; Kabanov, A.S.; Teplyakova, T.V.; Ibragimova, Z.B.; Makarevich, E.V.; Mazurkov, O.Y.; Shishkina, L.N. Antiviral properties of aqueous extracts isolated from higher basidiomycetesas respect to pandemic influenza virus. Mod. Probl. Sci. Educ. 2009, 5, 1-9.

321. Verma, A.K. Cordycepin: A bioactive metabolite of Cordyceps militaris and polyadenylation inhibitor with therapeutic potential against COVID-19. J. Biomol. Struct. Dyn. 2020, 1-8. [CrossRef]

322. Xu, H.; Li, S.; Lin, Y.; Liu, R.; Gu, Y.; Liao, D. Effectiveness of cultured Cordyceps sinensis combined with glucocorticosteroid on pulmonary fibrosis induced by bleomycin in rats. Zhongguo Zhong Yao Za Zhi 2011, 36, 2265-2270.

323. Dharsono, T.; Rudnicka, K.; Wilhelm, M.; Schoen, C. Effects of yeast (1,3)-(1,6)-beta-glucan on severity of upper respiratory tract infections: A double-blind, randomized, placebo-controlled study in healthy subjects. J. Am. Coll. Nutr. 2019, 38, 40-50. [CrossRef]

324. Geller, A.; Yan, J. Could the Induction of Trained Immunity by $\beta$-Glucan Serve as a Defense Against COVID-19? Front. Immunol. 2020, 11, 1782. [CrossRef]

325. Roberfroid, M.; Gibson, G.R.; Hoyles, L.; McCartney, A.L.; Rastall, R.; Rowland, I.; Wolvers, D.; Watzl, B.; Szajewska, H.; Stahl, B.; et al. Prebiotic effects: Metabolic and health benefits. Br. J. Nutr. 2010, 104 (Suppl. 2), S1-S63. [CrossRef]

326. Lao, E.J.; Dimoso, N.; Raymond, J.; Mbega, E.R. The prebiotic potential of brewers' spent grain on livestock's health: A review. Trop. Anim. Health Prod. 2020, 52, 461-472. [CrossRef] [PubMed]

327. Hetland, G.; Johnson, E.; Bernardshaw, S.V.; Grinde, B. Can medicinal mushrooms have prophylactic or therapeutic effect against COVID-19 and its pneumonic superinfection and complicating inflammation? Scand. J. Immunol. 2021, 93, e12937. [CrossRef] 
328. Popa, M.; Oancea, S. Studies on bioactive compounds of mushrooms and their potential antiviral effects against COVID-19. In Proceedings of the 44th Conference for Students of Agriculture and Veterinary Medicine with International Participatio, Novi Sad, Serbia, 15 December 2020.

329. Rahi, D.K.; Malik, D. Diversity of mushrooms and their metabolites of nutraceutical and therapeutic significance. J. Mycol. 2016, 2016, 7654123. [CrossRef]

330. Sakagami, H.; Takeda, M. Diverse biological activity of PSK (Krestin), a protein-bound polysaccharide from Coriolus versicolor (Fr.) Quel. In Mushroom Biology and Mushroom Products; Chang, S.T., Ed.; The Chinese University Press: Hong Kong, China, 1993; pp. 237-245.

331. Sagar, A.; Gautam, C.; Sehgal, A.K. Studies on some medicinal mushrooms of Himachal Pradesh. Indian J. Mushrooms 2007, 25, $8-14$.

332. Chai, R.; Qiu, C.; Liu, D.; Qi, Y.; Gao, Y.; Shen, J.; Qiu, L. $\beta$-Glucan synthase gene overexpression and $\beta$-glucans over-production in Pleurotus ostreatus using promoter swapping. PLoS ONE 2013, 8, e61693.

333. Ji, S.L.; Liu, R.; Ren, M.F.; Li, H.J.; Xu, J.W. Enhanced production of polysaccharide through the overexpression of homologous uridine diphosphate glucose pyrophosphorylase gene in a submerged culture of Lingzhi or Reishi medicinal mushroom, Ganoderma lucidum (higher Basidiomycetes). Int. J. Med. Mushrooms 2015, 17, 435-442. [CrossRef] [PubMed]

334. Guerrero-Torres, J.V.; Mata, G.; Martinez-Carrera, D.; Garibay-Orijel, C.; Garibay-Orijel, R. Primers for $(1,3)-\beta$-glucan synthase gene amplification and partial characterization of the enzyme in Ganoderma lucidum. Rev. Iberoam. Micol. 2013, 30, 267-270. [CrossRef]

335. Khan, A.A.; Gani, A.; Shah, A.; Masoodi, F.A.; Hussain, P.R.; Wani, I.A.; Khanday, F.A. Effect of $\gamma$-irradiation on structural, functional and antioxidant properties of $\beta$-glucan extracted from button mushroom (Agaricus bisporus). Innov. Food Sci. Emerg. Technol. 2015, 31, 123-130. [CrossRef] 